\title{
HIDING IN THE BUSHES: THE SOCIAL AND POLITICAL DYNAMICS IN NEAR- CAMPUS COMMUNITIES AND THE CASE OF STUDENT HOUSING IN HAMILTON, ONTARIO
}

\author{
by \\ A Major Research Paper \\ presented to Ryerson University \\ in partial fulfillment of the requirements for the degree of \\ Master of Planning \\ in \\ Urban Development
}

Toronto, Ontario, Canada, 2016

(C) Chris Erl, 2016 


\section{Author's Declaration}

I hereby declare that I am the sole author of this MRP. This is a true copy of the MRP, including any required final revisions.

I authorize Ryerson University to lend this MRP to other institutions or individuals for the purpose of scholarly research.

I further authorize Ryerson University to reproduce this MRP by photocopying or by other means, in total or in part, at the request of other institutions or individuals for the purpose of scholarly research.

I understand that my MRP may be made electronically available to the public. 


\title{
HIDING IN THE BUSHES: THE SOCIAL AND POLITICAL DYNAMICS IN NEAR- CAMPUS COMMUNITIES AND THE CASE OF STUDENT HOUSING IN HAMILTON, ONTARIO
}

\author{
Chris Erl, 2016 \\ Master of Planning \\ in \\ Urban Development \\ Ryerson University
}

\begin{abstract}
From the St. Scholastica Day Riots of 1355 to contemporary conflicts between residents and students, near-campus communities have been the sites of sustained and notable tension. A key factor in the cause of this tension is the short-term tenure of students in private-market rentals created from the conversion of single-detached residences. Using the case of student housing surrounding McMaster University in Hamilton, Ontario, an analysis of the location of privatemarket rentals and the perceptions of the established community of a 'creeping studentification' are tied to conflicts that effective planning strategies and municipal regulation can address.
\end{abstract}

Key words:

1. Student housing

2. Balanced communities

3. Studentification

4. Near-campus communities

5. Post-secondary institutions in Canada 


\section{Dedication}

To the Ryerson M.P1. class of 2016, who kept me inspired.

To my partner, James, who kept me focused.

To my parents, Judy and Ed, who kept me upright whilst I was on tenuous ground.

And to my fellow students of this generation, living in modest comfort, housed in universities, looking with unbending optimism into the future we will inherit. 


\section{Table of Contents}

Pg. 1 - Introduction

Pg. 5 - Existing literature

Pg. 6-Context

Pg. 6 - Study area

Pg. 8 - Student-resident conflicts

Pg. 11 - The lives of students

Pg. 14 - Variations in student housing

Pg. 19 - Terminology

Pg. 21 - Primary data

Pg. 21 - How data was collected

Pg. 22 - Issues with data collection

Pg. 23 - Analysis

Pg. 27 - 'Creeping studentification'

Pg. 32 - Recommendations

Pg. 37 - Conclusions and further study

Pg. 39 - Appendices

Pg. 53 - Sources 


\section{Table of Figures}

Figure One: University Enrollment Across Canada from 1951 - 2014

Figure Two: The neighbourhoods and sub-classifications of communities in West Hamilton

Figure Three: Lou Ferro-sponsored advertisements from May, 2012, in the Hamilton Spectator

Figure Four: McMaster's Residence Buildings

Figure Five: Purpose-Built Student Housing in Hamilton

Figure Six: Student houses by number of units

Figure Seven: Breakdown of identified student houses by rent, units, internal divisions, and gender restrictions

Figure Eight: Student Housing Location Heat Map in the Westdale/Ainslie Wood Area

Figure Nine: Percentage of Renters per census dissemination area in West Hamilton

Figure Ten: Median household income per census dissemination area in West Hamilton 


\section{Table of Appendices}

Appendix One: Neighbourhoods of West Hamilton

Appendix Two: Residence Buildings on McMaster's Campus

Appendix Three: Purpose-Built Student Accommodation in Hamilton

Appendix Four: Identified Private-market Single-Detached Student Rentals

Appendix Five: Walking Distances from McMaster's campus

Appendix Six: Student Housing Location Heat Map

Appendix Seven: Student Streets in Ainslie Wood West

Appendix Eight: Student Streets in Ainslie Wood

Appendix Nine: Student Streets in Ainslie Wood East

Appendix Ten: Student Streets in Ainslie Wood North

Appendix Eleven: Student Streets in Westdale South

Appendix Twelve: Student Streets in Westdale North

Appendix Thirteen: Land Uses in Ainslie Wood

Appendix Fourteen: Land Uses in Westdale 
"They film late into night, from behind bushes, in disguise for fear of reprisal, to capture what they label a "drinking problem" that starts on campus... Formed this summer, Westdale Against Drunk Students (WADS) includes dozens of [McMaster's] closest neighbours east of campus, mostly on Forsythe near Sterling," (Falkner, 2006).

"The neighbourhood's up in arms

They're trying to shut down all the bars

When everyone's a private eye

They're hiding in the bushes every night."

-from "John Lennon" by the Arkells, 2008

\section{Introduction}

In 1967, the Association of Universities and Colleges of Canada commissioned a report on the nature of student housing across the country. Completed nearly two years later by a team of planners, architects, and consultants led by Henry Sears, the final product outlined a complicated, worsening housing situation for post-secondary students. Providing a poignant articulation of why understanding the student housing situation in Canada was important, Sears wrote in the preface:

"Students are at university for a very short period in their lives. It is a unique and critical time for them. It is not only what they learn that is important. The ways in which they learn, the ways in which they mature, the ways in which they acquire both their wisdom and their skills, will have a profound impact upon them and, as they move through life and society, upon the people and community around them. When we began this study, common sense and our own academic experiences suggested that how a student lives is important to his intellectual and emotional development. After more than a year and a half of intensively examining and analyzing student housing, we are even more convinced of it." (Sears, 1969)

The report concluded with a call for further study, a call that has gone unheeded in the 47 years since its release. In the years since "Room to Learn" was published in 1969, universities have changed considerably. Campuses have grown, financial pressures have changed the nature of 
academic discourse and service delivery, and technology has reshaped the way students learn and interact with their campuses.

The change in number of students in Canadian universities is striking. University enrollment across the country has increased from 64,000 in 1951 to 294,000 in 1969 , and peaking at 1.3 million in 2014 (Statistics Canada, 2014, 2015).

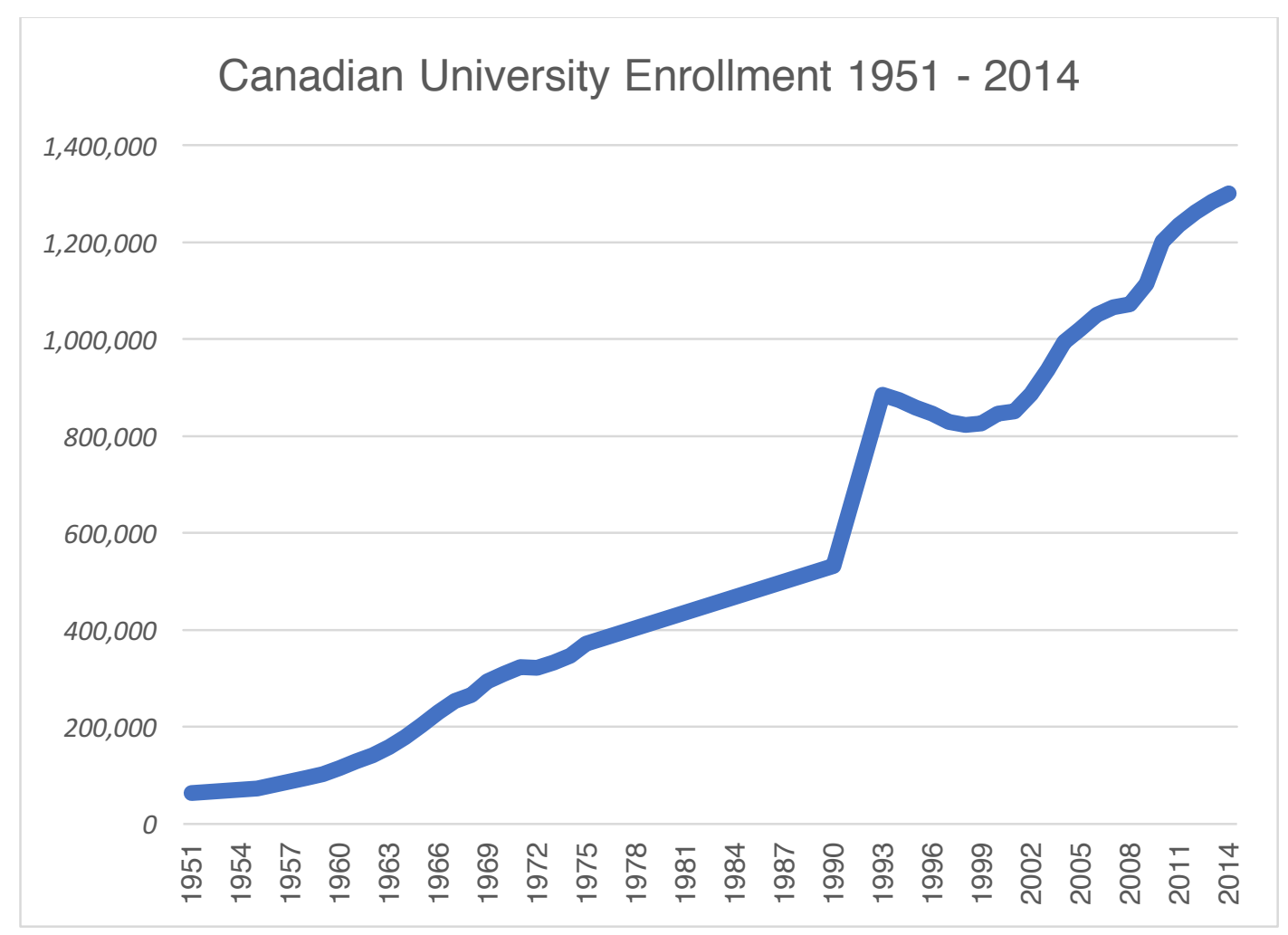

Figure One: University Enrollment Across Canada from 1951 - 2014

As enrolment has increased, the priorities of universities have changed, shifting from providing a collegial environment for students that includes accommodation, to focusing their efforts on providing study space for students and reemphasizing on-campus deferred maintenance.

The provision of accommodation has fallen, largely, to the private market, with two distinct kinds of housing coming to dominate the student market: private market rentals and purpose-built student developments. These will be investigated in-depth in later chapters. 
As much as universities and the student housing situation both on- and off-campus have changed, there are still key issues that remain unstudied and unaddressed. The over-concentration of converted single-detached private market student rentals in certain communities raises tensions as landlords fail to engage with the community, residents see the presence of these properties as a sign of decline, and students seek to develop both a sense of home and of their collective identity during a formative time in their lives that often conflicts with the established identities of existing residents. These tensions, though well-documented in the media, must be understood within the context of Canada's university culture. Planning and policy solutions, at present not uniformly applied, must be better understood. The role purpose-built student accommodation can play in alleviating these tensions, providing a safe and supportive environment for students, and reducing conflicts between students and residents deserves considerable attention from academics.

For the purposes of this study, the focus will be on understanding the current student housing situation and where students chose to locate. The attempt of this study is to draw from theories presented in existing academic sources, a survey of local media, and independent data collection, to more fully understand if a concentration of students in particular areas is linked to conflicts, particularly when local residents perceive a substantial shift in their community. Using the case study of the near-campus communities surrounding McMaster University in Hamilton, Ontario, the sites of these conflicts will be analyzed to determine if tensions arise near where the studentto-resident ratio has reached a 'tipping point'. This 'tipping point' occurs on a street-by-street basis and has the potential to unbalance the surrounding community. Streets that exhibit a lack of balance lead existing residents to feel isolated, and cause residents near these 'unbalanced streets' to fear their street will be the next to become, as one local resident put in a letter to the Hamilton Spectator, "student-infested" (Robinson, 2007). The fear of a loss of community fuels tensions, which can be 
alleviated through a strong system of planning regulation that encourages balanced communities that expressly ensure students are respected as key contributors to the neighbourhoods in which they live for the duration of their time at post-secondary institutions.

This study provides an overview of the existing literature available on the issue, examines the chosen study area, highlights key pieces of secondary research that will inform the proposed solutions, and examines the unique data collection that occurred for the purposes of this analysis. Following these segments, it establishes that the transitory nature of students and their maintaining residence in student accommodation for select portions of the year raises concerns regarding consistency in tenure. The proposed solutions highlight that, without regulation, gaps in the fabric of communities appear, which exacerbate issues that would otherwise be addressed in moreestablished neighbourhoods. Finally, local policies and planning strategies that can be tailored toward creating mixed, diverse communities, some of the issues can be alleviated and cohesion can be reestablished are examined. 


\section{Existing Literature}

On the topic of student housing in Canada, little academic research has been conducted and published. Of the few sources available, Charbonneau, Johnson, and Andrey's 2006 study of the potential for student housing to play a role in urban revitalization is the most notable. In this study, the authors establish hypothesis surrounding the desire for students to live within walking distance of their campuses. This study was relied upon considerably for the purposes of this investigation.

A significant majority of the academic literature relating to this field comes from the United Kingdom, where researchers have been studying the issue they have deemed 'studentification' since the mid-1990s. Kenyon (1997), Munro, Turok, and Livingston (2009), and Sage, Smith, and Hubbard (2012) have each contributed to the United Kingdom's growing body of literature on student-resident conflicts, examining the seasonal nature of student communities, the geographic concentration of student housing, and the trigger events that cause tension, respectfully.

Smith (2008) follows the same general sentiment, but focuses his analysis on government policies that have enabled student communities to reach points where conflict becomes reality. Focusing on the lives of students, Selwyn (2008) provides insight into the minor criminal acts that students commit and provides a foundation for understanding why tensions flare in near-campus communities.

Outside of the United Kingdom, researchers in Norway have been analyzing notions of 'home' and identity in housing among students. Most notably, Judith Thomsen, publishing a 2007 original piece on the physical characteristics of student housing in Norway, and collaborating with Terje Eikemo in 2010 on perceptions of home, has helped establish how students conceptualize their living situation for their time at university. 


\section{Context}

$\underline{\text { Study area }}$

McMaster University

McMaster University is a public Canadian research university and member of the U15 Group of Canadian Research Universities. Founded as a Baptist college in 1887 through an endowment by Canadian Imperial Bank of Commerce founder William McMaster, the university was originally based on Bloor Street in Toronto (McMaster, 2016). The university moved to its current Hamilton campus in 1930 after an intensive effort by the developers of the Westdale community to entice the school through donations and land assembly (Weaver and Doucette, 1991).

The university boasts an enrolment of 22,558 undergraduate students, 3,519 graduate students, and 958 full time faculty as of 2015/2016 (McMaster, 2016). As such, McMaster is the $18^{\text {th }}$ largest university in Canada and the $7^{\text {th }}$ largest university in Ontario.

\section{The surrounding community}

The community that supports McMaster, Hamilton, is the $10^{\text {th }}$ largest city in Canada, with a population of 519,950 as of 2011 . Though Hamilton is the central area of focus for this study, the the study area within the city was determined based on assertions developed in previous academic analyses on the topic. Based on Charbonneau, Johnson, and Andrey's assertions regarding the desire for students to remain in close proximity to their campus, this study began with the entrances to McMaster University as a starting point and calculated the walking distance at intervals of 800 metres, or roughly 10 minutes of walking time, stopping at $2.4 \mathrm{~km}$, or 30 minutes of walking to determine an appropriate area of geographic focus. As such, this study will consider student housing located within this radius, which incorporates Hamilton's Westdale, Ainslie Wood, 
Kirkendall, and Strathcona neighbourhoods in the city's Ward One, and the former municipality of Dundas, Hamilton's Ward Thirteen.

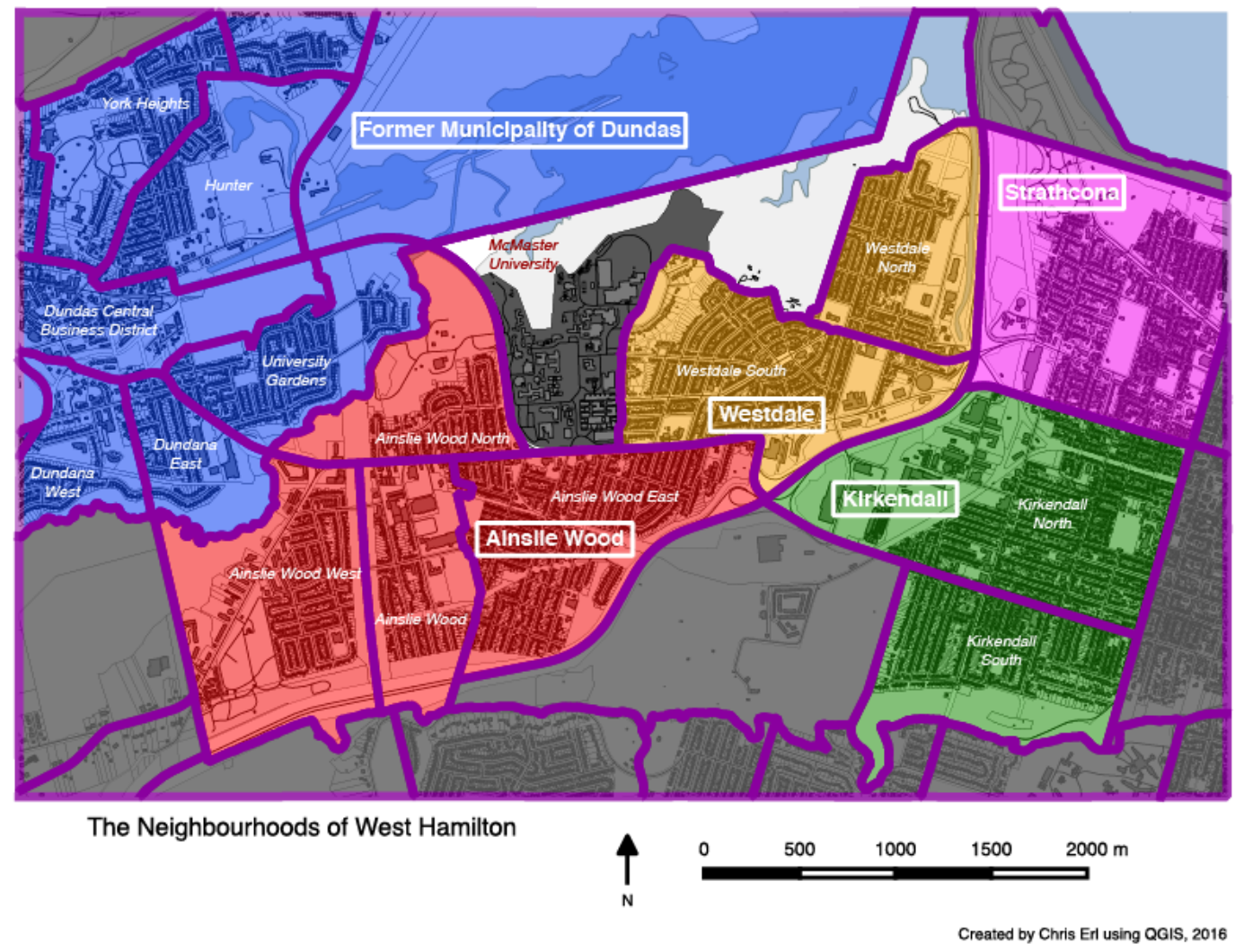

Figure Two: The neighbourhoods and sub-classifications of communities in West Hamilton

McMaster University is located in Hamilton's Cootes Paradise neighbourhood, named for the adjacent body of water that serves as a northern border for the university. McMaster is the dominating feature in this neighbourhood, which retains no population aside from the students who live on campus. McMaster itself is bounded by the Westdale neighbourhood to the east and the Ainslie Wood neighbourhood to the south and west. These neighbourhoods are further divided into smaller units. 
Westdale is a well-established community in Hamilton, with the construction of the first tracts beginning in 1920 and the final original components of the community being completed in 1944 (Doucet and Weaver, 1991). Home to an active central business area and affluent population, the area is a well-recognized and distinct community within the city that maintains a strong community association, which has often been at the forefront of the student housing issue. The activities of the community and their organized advocacy group will be discussed at length in later chapters.

The Ainslie Wood neighbourhood to the south and west of the campus was developed later than Westdale, though two distinct portions of the community, namely the area between Emerson Street and Bowman Street known as the Burke Survey and a segment of the community south of Westwood Avenue that was developed as a housing survey for veterans, are designated as Cultural Heritage Landscapes by the City of Hamilton (City of Hamilton, 2013).

Beyond the Westdale community lies a hard edge in the form of the Highway 403, which cuts through a historic river that created a deep channel which physically separates Westdale from the rest of west Hamilton. The two neighbourhoods to the east of Westdale, Strathcona and Kirkendall, were settled around the time of Confederation, but came into full form around the turn-of-thecentury (Smith and Randall, 2008). Further to the west of Ainslie Wood lies Dundas, a formerly independent municipality that was amalgamated into Hamilton in 2001. Dundas maintains a very strong independent culture, seeking to differentiate itself from the rest of Hamilton.

\section{$\underline{\text { Student-Resident Conflicts }}$}

The adversarial relationship between students and residents has been traced back to the St. Scholastica Day riot on February 10, 1355, which saw hundreds of people killed and the relationship between Oxford University and townsfolk irrevocably altered (Hundscheid, 2010).

Though that particular event was an extreme example of a conflict between students and 
residents, minor confrontations have continued on to the present day, many of which are focused on student housing. In Hamilton, conflicts between students and residents are generally confined to Westdale and Ainslie Wood, with the former neighbourhood serving as the most politically active and hostile to student housing. The perspectives of homeowners and students were summarized effectively in 1997 when the Hamilton Spectator noted,

"For investors, [student] rentals are a profitable cash business. For students it's the place they temporarily call home. What's at stake for residents is the permanent character of their neighbourhood," (Simpson, 1997).

While there have been few incidents of actual violence in the community, the student housing situation in the area became particularly tense in the early 2000s. In 2003, an article was submitted to the Hamilton Spectator by the adult son of a Westdale resident who bragged about bringing friends who looked "intimidating" with him to a student house where he "invited" himself in and threatened the student occupants. The author, expressing the tenseness of the situation, wrote that he, "told them about wanting to beat one of them senseless," (Peters, 2003).

In 2005, a group of 50 Westdale residents staged a protest in front of a single detached house they believed to be undergoing a conversion into a private market rental (Mckay, 2005). Tensions worsened the following year when a group organized to combat what they perceived to be an issue with intoxicated students in the community. Named Westdale Against Drunk Students, or WADS, the group was led by a local lawyer, Lou Ferro, who threatened the university with lawsuits and filmed students as they walked through the community in the hopes of catching them engaging in inappropriate behaviour (Faulkner, 2006). During that year's municipal election, local councilor Brian McHattie's campaign was met by protestors who demanded action on the area's student housing situation (Macintyre, 2006).

Following McHattie's re-election in 2006, the councillor engaged the McMaster Student Union 
and the area's community council, the Ainslie Wood/Westdale Community Homeowners Association (AWWCA), in a series of programs aimed at addressing property standards issues and the relationship between residents and homeowners.

These programs eased tensions until the McMaster Graduate Student Association sought to move their campus pub, The Phoenix, to a new location. This required the issuing of a new liquour licence, which brought Ferro into conflict with McMaster once more. Ferro's group, now renamed Parents Against Drunk Students (PADS) after the previous name was mocked by students and the Juno Award-winning rock group, the Arkells, for its colloquially inappropriate connotations, took out ads in the Hamilton Spectator (Cummings, 2014). The new licence, which would have seen the 443-guest bar at the university' Sterling Street entrance in Westdale moved to a smaller 362guest location on the western edge of campus, was approved despite Ferro's attempts to block the move (Howard, 2012).

Following the Phoenix relocation debates, there have been a series of smaller incidents which have been documented well in the local media. A series of house parties during the opening days of the 2015 fall term led to residents and Ward One's new city councillor, Aidan Johnson, asking McMaster to better manage off-campus drinking (Dreschel, 2015).

Recent tensions have focused on Ainslie Wood, as rental housing expansions in the community have come under attack by residents. Galvanized by the closure of the last public elementary school in the community in 2014, residents have become more active, forming their own break-away community group, the Ainslie Wood Community Association (AWCA), and battling rental conversions in the area (Fragomeni, 2015). A violent attack at an Aylett Street student party on St. 


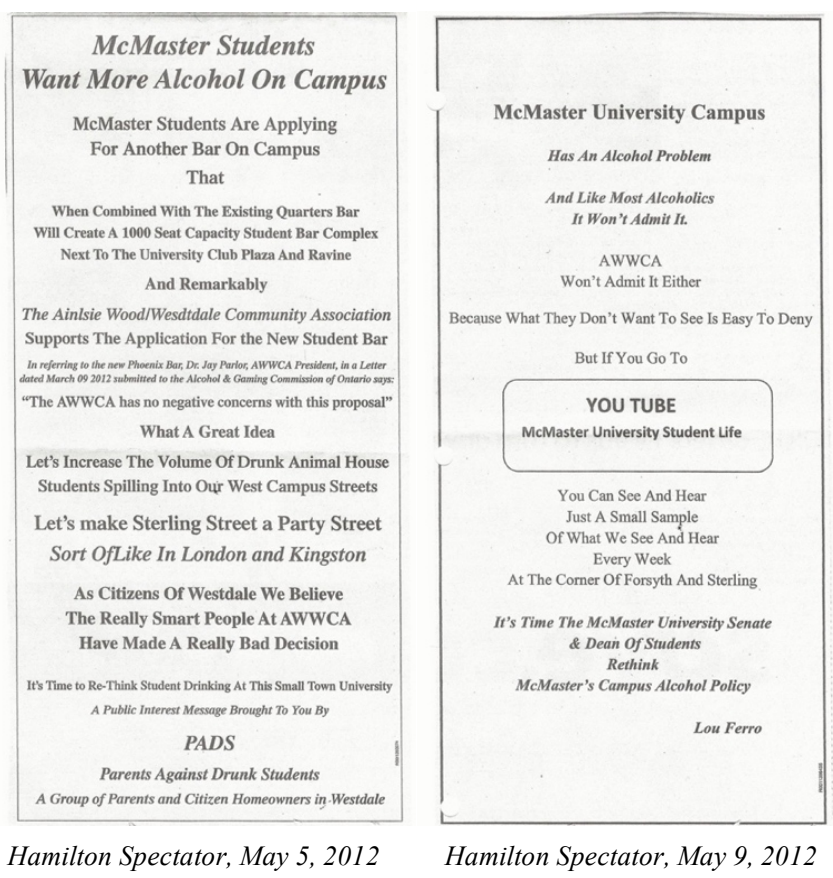

Figure Three: Lou Ferro-sponsored advertisements from May, 2012, in the Hamilton Spectator

Patrick's Day, 2015, raised community concerns and pushed local residents to seek assistance from local officials in dealing with the unbalanced nature of their community (Fragomeni and Nolan, 2015). Events such as the St. Patrick's Day stabbing have led the AWCA to become more active in opposing student housing, most recently opposing a proposed purpose-built student development on the grounds that such a development would be "undesirable" (AWCA, 2015).

The lives of students

The conflicts that arise between students and residents stem from the differences in experiences, values, and opinions of permanent residents and student occupants. Research regarding student experiences in university and private-market housing from around the world points to a holistic conception of 'home' amongst students. Home is viewed as a place where self-identity can be developed and flourish, particularly among students who had previously never lived independently of their parents (Thomsen, 2007).

In their 2010 survey of students in Norway, Thomsen and Eikemo made the poignant 
observation that,

"A home is more than the physical building. It is a place that people attach either a positive or a negative meaning to. Moreover, a home is also shaped and adjusted by its inhabitants to express their identity," (Thomsen and Eikemo, 2010).

Students use their homes and their surroundings to develop their individual identities in unique and deeply personal ways. While individual identities are being formed, a collective identity also emerges, deeply rooted in the traditions of the university communities in which they find themselves and the housing situations that characterize these communities. These collective identities are undoubtedly impacted by the isolation from other residents felt by students whilst living in near-campus communities. Gumprecht's analysis of the community surrounding Cornell University highlighted the struggle to establish a collective identity and the subsequent geographic separation between groups. He highlights the situation in the United States, where the collective identities of students can involve association with fraternities or sororities, progressive political values, and differing forms of social activism. He notes that these values, and the state of the homes in which students reside, pressure existing residents to seek spaces that represent their collective identity, leading to pockets of distinct communities within communities. Importantly, Gumprecht found that, "College faculty and other permanent residents seldom want to live near undergraduates because of the different lifetyles they lead," (Gumprecht, 2006).

The geographic separation, as Gumprecht notes, because of a difference in values and lifestyles, is further punctuated by the ways in which students project their burgeoning identities on their surroundings. In Oxford, Ohio, students at Miami University affix signs to their student homes with 'house names' that reflect the personalities of the residents within, from religious allusions to puns and sexual innuendo (LaDousa, 2007).

McMaster, too, has a series of traditions that aid students in developing their collective identity. 
During the first week of classes in the fall term, student leaders from each of McMaster's faculties and residence buildings will don mechanic's overalls in different colours and serve as 'Welcome Week Representatives', or 'Reps'. These Reps will guide incoming students around campus, showing them where different facilities and classes are, while also engaging them in activities meant to demonstrate the culture of their respective residences and faculty divisions (science, humanities, engineering, etc). While some events aim to work with the surrounding community, such as the yearly Pajama Parade down Sterling Street which incorporates members of the AWWCA and the university administration, other events have earned the ire of the community (McMaster, 2015). The Engineering Reps, colloquially referred to as "Redsuits" have, in the past, engaged in a series of unsanctioned events that have involved alcohol, vandalism, and sexuallycharged behaviour that have resulted in complaints from residents and other faculities. Following the 2014 discovery of a book of chants and songs that advocated violence against women, McMaster hired outside consultants to examine the culture that was being passed on to incoming students as to provide a more supportive environment and alleviate some community concerns (Bradshaw, 2014).

Though not all attempts at developing a unique collective identity are as extreme and degrading as the events surrounding McMaster's Engineering Reps, academic analyses have found students committing what are considered 'minor crimes' as a way of further developing a sense of self and engaging more fully in what they perceive to be a 'university culture'. A 2008 survey of students in the United Kingdom found that students, in particular male students, committed minor crimes, often involving alcohol, in part because of what they identified as a newfound 'lack of supervision' and the melding of different social circles with different life experiences and values (Selwyn, 2008). 
From the positive attempts to negative incidents, students will use the opportunities afforded them by their housing independence and unique community to develop a personal and collective identity. As these identities may not clearly align with the perceptions of community and home maintained by permanent residents, the spaces in which students attempt to develop these identities may become points of conflict. Serious events in these spaces may trigger organized oppositional efforts that can further alienate students, The variations in student housing

In order to effectively understand the student housing situation in Canada, it is important to fully define the forms of housing available to students. ${ }^{1}$ These classifications are broad, and are meant to incorporate as many sub-varieties of student accommodation as possible.

\section{Residence}

The provision of student housing in residence halls, colloquially referred to as 'residence' in Canada, was an essential component of the original campus plans of Canadian universities. At McMaster, residences were considered to be an integral component of the academic community. When the university relocated to Hamilton in 1930, the campus plan set aside space for a male and female residence, which today stand as Edwards Hall and Wallingford Hall (Robb, 1970). They have been joined by 10 additional residence buildings in the time since 1930 .

\footnotetext{
${ }^{1}$ This study does not take into account students who commute from their parental home or the home of a relative. There are distinctly different issues facing commuter campuses and the communities that house them, as well as commuting students. Investigating that situation is also necessary, but was not incorporated into this study due to resource and time constraints.
} 


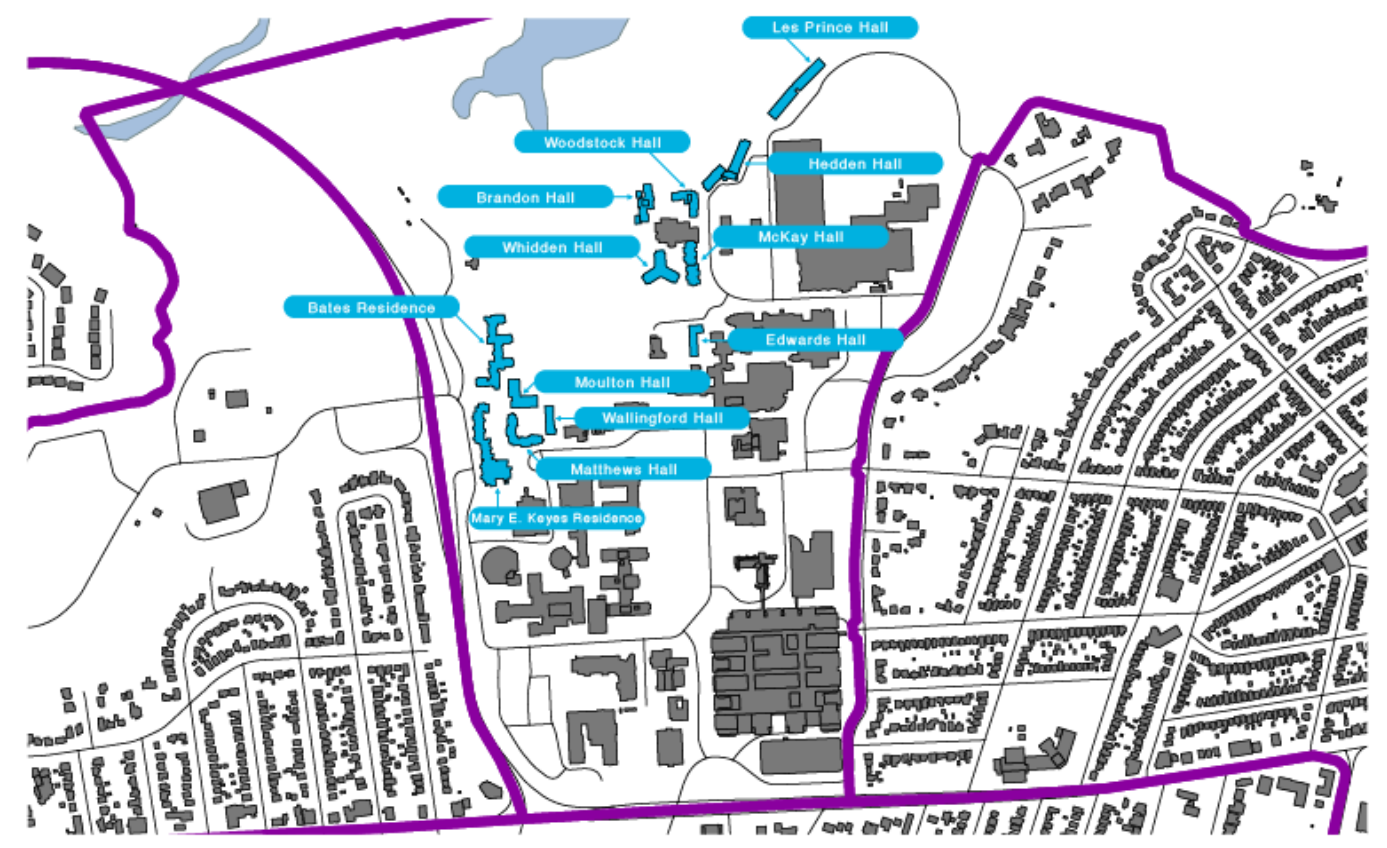

Residence Buildings on McMaster's Campus

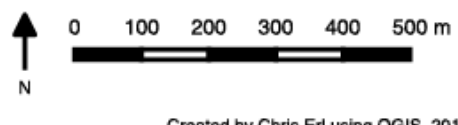

Figure Four: Residence Buildings on McMaster's Campus

Since the 1970's, little research has been conducted on the effectiveness of residence in meeting the needs of either the university or students (Devlin, et. al., 2008). Of the research that has been completed, two distinct opinions arise: one critical of the institutional nature of residence and one that promotes the role of residence in providing a support network for students at a vulnerable time in their lives.

The critical opinion focuses heavily on past trends in residence construction and their stifling of individuality and creativity. A 1970 report prepared for McMaster on the state of its student housing situation noted that the university's stock of residence buildings at the time imposed, "unnatural restraints without benefit of academic involvement or intellectual stimulation," (Robb, 1970). Academic interviews conducted with students in Norway saw them connect their lack of 
affection for residences with predicable, institutional layouts, which separates students from a perception of 'home' (Thomsen, 2007).

In support of residence are studies that indicate support networks are essential to improving the mental health situation of students and helping them more fully define themselves as people (Friedlander, et. al., 2007).

\section{Private-Market Rentals}

Private market rentals, or 'student houses', illicit strong reactions from individuals in or near communities where these type of properties are a feature. These are generally single-detached homes purchased by private investors and converted from 2 or 3 bedroom residences into 4 to 10 bedroom rooming houses (Rugg, Rhodes, and Jones, 2002). These rental properties are associated with a wide-array of bylaw violations and concerns. A 1997 article from the Hamilton Spectator opened with a description of the perceived state of a neighbourhood after its proliferation by student rental homes:

"Weeds the height of toddlers. Cars parked on the lawn. Late night noise that will vibrate neighbouring floorboards. Beer bottles instead of petunias on the porch...Residents say the problem is absentee landlords who buy the homes as an investment, turn them into rabbit warrens, collect the rent, and let the property decay," (Simpson, 1997)

Research from the United Kingdom has established two distinct kinds of property owner: the traditional landlord and the entrepreneur landlord. These types of landlord provide housing that is in high demand, regardless of its condition due to the general adaptability of students (Rugg, Rhodes, and Jones, 2002). 
It was primarily this type of student accommodation that was investigated for the purposes of this study, as the geographic disbursement and community sentiment surrounding private-market rentals was identified as a primary factor in contributing to the unbalancing of a community.

\section{Purpose-Built Developments}

A recent trend in the provision of student housing is purpose-built student development. Purposebuilt developments can be new constructions or refurbishment of existing structures to accommodate for student living. These developments are private versions of university residence buildings, sometimes offering extra amenities or alternative room sizes. Purpose-built developments are not constrained by ties to universities and can, therefore, be sited in downtown locations or further from campus. While students prefer proximity to campus, purpose-built developments offer easy access to other amenities that some students will prioritize over the distance traveled to attend class, such as local night clubs, restaurants, museums, shopping districts, and public transit infrastructure (Hubbard, 2009). In the United Kingdom, local authorities are investigating the potential for purpose-built developments to alleviate community tensions and concerns, as well as serving as a catalyst for urban renewal in downtown cores (Hubbard, 2009). Research from Canada also points to the potential for student housing to serve as a revitalizing agent, though these studies found the desire for accommodation close to a central campus is far greater than any desire to be near local amenities (Charbonneau, Johnson, and Andrey, 2006).

There are a number of purpose-built developments in Hamilton that cater to students at McMaster. Hamilton's social housing provider, CityHousing Hamilton, offers apartments specifically for post-secondary students at a building it operates at 191 Main Street West. Rent at 191 Main Street West is $\$ 542$ per month and the city highlights the local amenities, such as 
proximity to Hamilton's nightclub district, Hess Village, as a feature of the building (CityHousing Hamilton, 2014). The largest private purpose-built development is West Village Suites, a 9-storey apartment tower reserved exclusively for students at the western edge of the Ainslie Wood North community. Built in 2005, the tower contains 109 units that range from 2 to 5 bedrooms, housing 449 students, and featuring ground-floor retail and a LEED-Platinum certification. At the same time West Village Suites was under construction, the project developers completed five multiplex homes in the Strathcona neighbourhood they called the Dundurn Student Residence (Mewdell, 2004).

There are a series of smaller purpose-built student residences in Hamilton, some of them conversions of former schools and office buildings, and, in one extreme example, an underperforming strip mall. The strip mall, in the Westdale South neighbourhood, was quickly converted in 2005 to student housing with each of the five commercial units being outfitted with four bedrooms each, despite the middle three units not having any side windows or light access (Wilson, 2005).

New purpose-built projects have been controversial, such as the aforementioned suggested development in Ainslie Wood East that received considerable opposition from the AWCA. Alternatively, a 146-unit, 21-storey student housing and infill project in the downtown core was approved by Hamilton's planning committee in February of 2016 (Fragomei, 2016). Other purpose-built projects have been proposed, but many change form multiple times prior to their going to the City of Hamilton's planning committee for approval. 


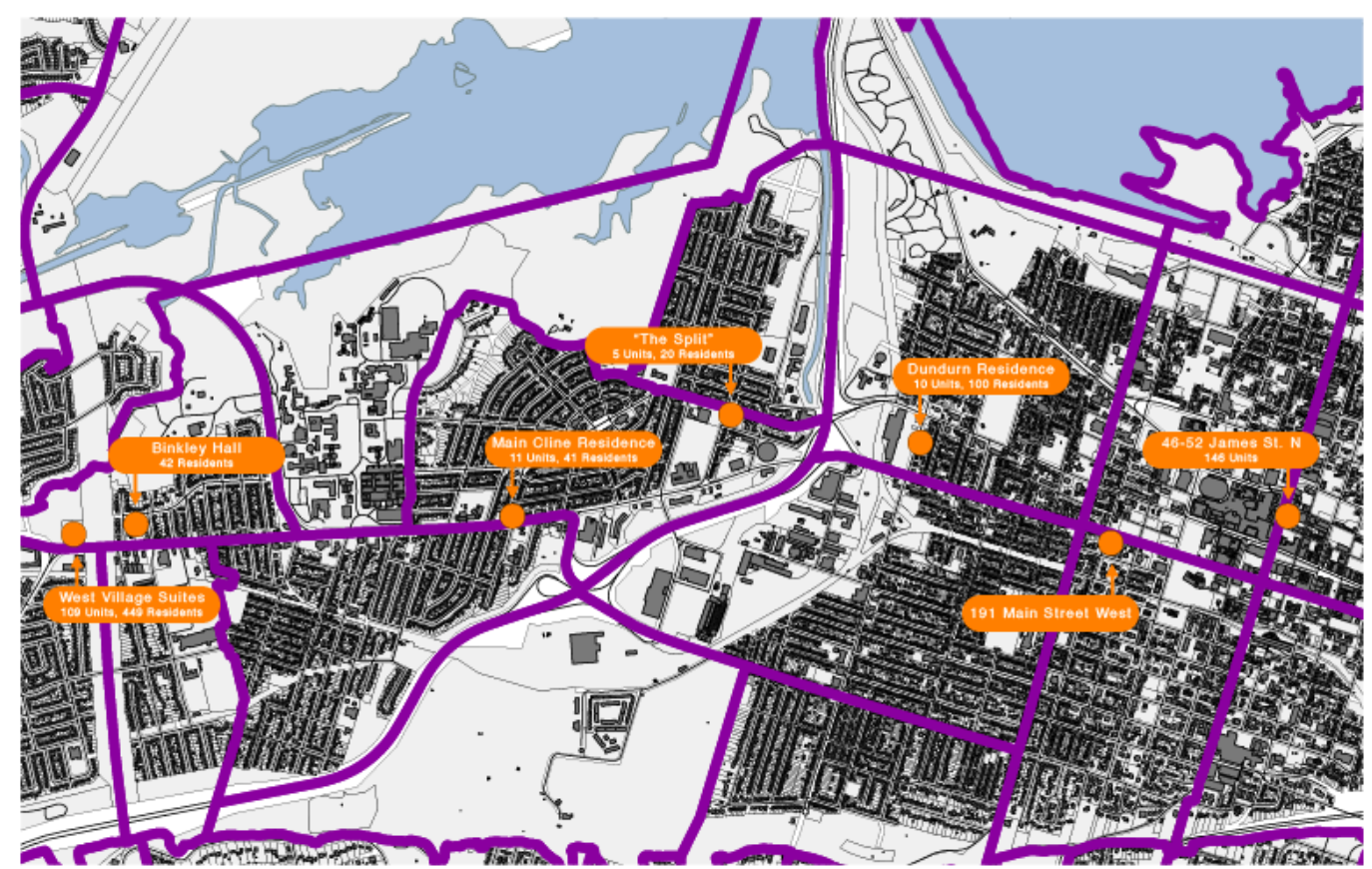

Purpose-Built Student Accomodation in Hamilton

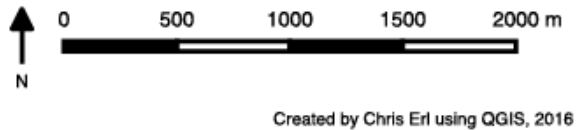

Figure Five: Purpose-Built Student Housing in Hamilton

\section{Terminology}

There are colloquial terms used to define forms of student accommodation and areas that have come to be dominated by private-market rentals. In some cases, these terms are useful and unproblematic. Often, there are multiple terms for a specific kind of residence, such as "private market rentals' and 'student houses', which broadly mean the same thing and can be used interchangeably to describe a similar housing situation. There is one term that will not be used in the context of this study, though. Reference to a geographic area associated with students as a 'student ghetto' is highly problematic and unrepresentative of the situation present within these communities. The historical origins of the terminology are associated with forced segregation of 
disempowered, and often racialized, groups, and those historical origins cannot be separated from contemporary usage of the term (Domonoske, 2014). To associate this terminology with student areas ignores the privileges present among some students and others students as a community in relation to wider society. The more reflective term 'near-campus community' will be used for the remainder of this study. 


\section{Primary data}

\section{$\underline{\text { How data was collected }}$}

Over the course of 14 months, data was collected from the McMaster Off Campus Resource Centre's online classified site (https://macoffcampus.mcmaster.ca/classifieds/), the sites of local property management companies, and other rental websites such as Kijiji.ca and compiled on a spreadsheet that indicated the number of rooms in each home, whether the building was divided into separate spaces with units in each part, was a whole unit, or was any combination, and relevant contact information. The time frame was selected as properties are listed at varying time of the year, with the period between December and February serving as a busy one for students seeking accommodation for the coming academic year. Some effort was made to compile data on whether rent included utilities and any extras, as well as interesting or relevant information on the property, but this was done inconsistently due to lack of availability of such information, and has been excluded from analysis. This data was subsequently mapped in relation to properties in Hamilton providing the foundation for the analysis of the concentration of student housing and the proximity of units to the edges of McMaster's campus.

The location of purpose-built student housing developments was determined as well. For this study, 'purpose-built' incorporates large developments that were constructed for the purposes of housing students, structures that underwent conversions to become student residence buildings, and developments that have been approved by Hamilton's planning committee. Additionally, the location of McMaster's existing and proposed residence buildings was established, as indicated on the map in Figure Four. 


\section{$\underline{\text { Issues with data collection }}$}

Initially, five municipalities were selected for their distinct, while still similar, near-campus situations. Each of the selected municipalities has at least one public university with which it is affiliated and a recognizable near-campus community. Additionally, these municipalities and their student housing situations had been the subject of discussion in popular media. These were:

- London (Western University),

- Ottawa (University of Ottawa and Carleton University),

- Oshawa (Ontario University Institute of Technology),

- Hamilton (McMaster University), and

- Kingston (Queen's University).

From this list, both Oshawa and Kingston did not have readily-available datasets and were excluded. After corresponding with the planning and bylaw departments of London, Ottawa, and Hamilton, the municipalities provided different datasets, making a cross-jurisdictional analysis very difficult.

McMaster University, the University of Ottawa, and Western University all provide off-campus housing resource websites with online message boards that link to available rental homes and the details of these properties. McMaster and Western provided the most comprehensive lists.

Working within the time-frame of this project, the available data sets and off-campus housing listings, the most effective analysis was conducted on the student housing situation around McMaster in Hamilton. Both a comprehensive, cross-jurisdictional analysis and an analysis that incorporated surveys of student and homeowner opinions would be recommended in the future. 


\section{Analysis}

Over the 14 months of data collection, 755 private market rentals were identified, mapped, and analyzed based on their geographic location and density. A number of other rentals that appeared on the McMaster Off-Campus Resource Centre's website, such as apartment buildings that were not exclusively geared toward students, were also identified, but were excluded from analysis. Of those 755 units, only five fell outside the Westdale and Ainslie Wood neighbourhoods. Three were located in the former Municipality of Dundas while two were in the Strathcona neighbourhood.

The location of identified student housing confirms the assertions made by Charbonneau, Johnson, and Andrey that students seek to live as close as possible to their campus, which they attributed to both accessibility and a student culture present in the near-campus area (2006).

Information surrounding the characteristics of the units was collected where available, as listings on the sites used for data collection did not require landlords or listers to provide all the available information about the location. 460 of the properties listed the monthly rent-per-unit, which ranged from $\$ 300$ per month to $\$ 875$ per month with an average monthly rent of $\$ 436$. A total of 451 of the listings indicated the number of units in each house, ranging from two to ten units per house with an average number of 5.87 .

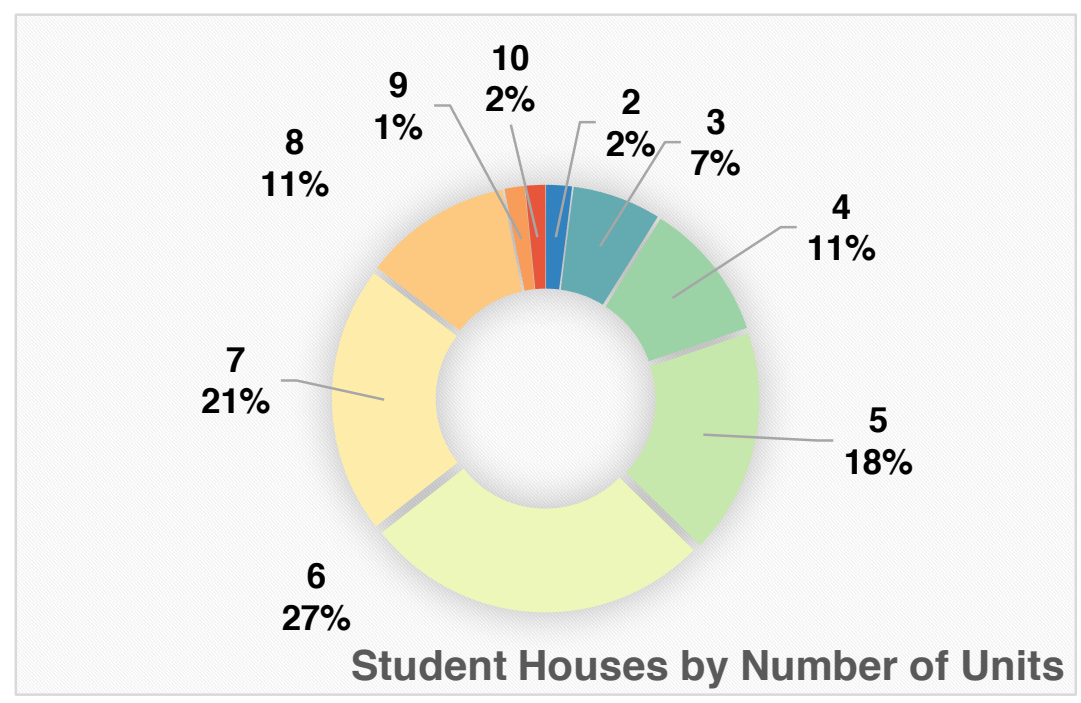

Figure Six: Student Houses by Number of Units 


\begin{tabular}{|c|c|c|c|}
\hline \multicolumn{4}{|c|}{755 Identified Student Houses } \\
\hline RENT & UNITS & INTERNAL DIVISIONS & GENDER \\
\hline $\begin{array}{c}460 \\
\text { listed rent-per-unit }\end{array}$ & $\begin{array}{l}\mathbf{4 5 1} \\
\text { listed number } \\
\text { of units per } \\
\text { house }\end{array}$ & $\begin{array}{c}\mathbf{4 2 8} \\
\text { indicated if the house } \\
\text { was full, divided, or } \\
\text { flexible }\end{array}$ & $\begin{array}{l}\mathbf{4 7} \\
\text { listings specified a they } \\
\text { would only rent to a } \\
\text { particular gender identity }\end{array}$ \\
\hline $\begin{array}{l}\text { Rent ranged from } \\
\mathbf{\$ 3 0 0} \text { per month to } \\
\mathbf{\$ 8 7 5} \text { per month }\end{array}$ & $\begin{array}{l}\text { Number of } \\
\text { units ranged } \\
\text { from } \mathbf{2} \text { to } \mathbf{1 0}\end{array}$ & $\begin{array}{c}367 \\
\text { houses were rented } \\
\text { without division }\end{array}$ & $\begin{array}{l}\mathbf{3 6} \\
\text { listings would only be } \\
\text { rented to female identified } \\
\text { individuals }\end{array}$ \\
\hline $\begin{array}{l}\text { Average Rent was } \\
\mathbf{\$ 4 3 6} \text { per month }\end{array}$ & $\begin{array}{c}\text { Average } \\
\text { number of units } \\
\text { was } \mathbf{5 . 8 7}\end{array}$ & $\begin{array}{c}\mathbf{4 2} \\
\text { had } 2 \text { or more separate units } \\
\text { inside a single detached } \\
\text { residence and } \\
\mathbf{1 9} \\
\text { could be made to } \\
\text { accommodate a large group } \\
\text { or multiple smaller groups }\end{array}$ & $\begin{array}{l}\mathbf{1 1} \\
\text { listings would only be } \\
\text { rented to male identified } \\
\text { individuals }\end{array}$ \\
\hline $\begin{array}{l}295 \text { did not list rent- } \\
\text { per unit }\end{array}$ & $\begin{array}{l}304 \text { did not list } \\
\text { number of units }\end{array}$ & $\begin{array}{c}327 \text { did not indicate the } \\
\text { interior structure of the } \\
\text { house }\end{array}$ & $\begin{array}{l}708 \text { did not restrict } \\
\text { tenancy to a specific } \\
\text { gender identity }\end{array}$ \\
\hline
\end{tabular}

Figure Seven: Breakdown of identified student houses by rent, units, internal divisions, and gender restrictions

Of the listings that indicated housing structure, 367 of the listings were for full houses with separate bedrooms and central facilities and 42 of the listings indicated that the house was split, with separate entrances to stand-alone apartment units in one single-detached structure. A further 19 listings asserted that the homes could be divided if two groups of students wanted to rent independently of one another or could be made to accommodate larger groups in a full house. 327 listings did not provide any indication as to the interior division of the home. 36 of the listings indicated that the units would only be rented to female-identified individuals, 11 listings stipulated that units would only be rented to male-identified individuals, while 708 did not restrict tenants 
based on gender. While many listings indicated that quiet, mature students would be 'preferred', only one established cultural criteria, expressing a preference for renting to a student of South Indian origin.

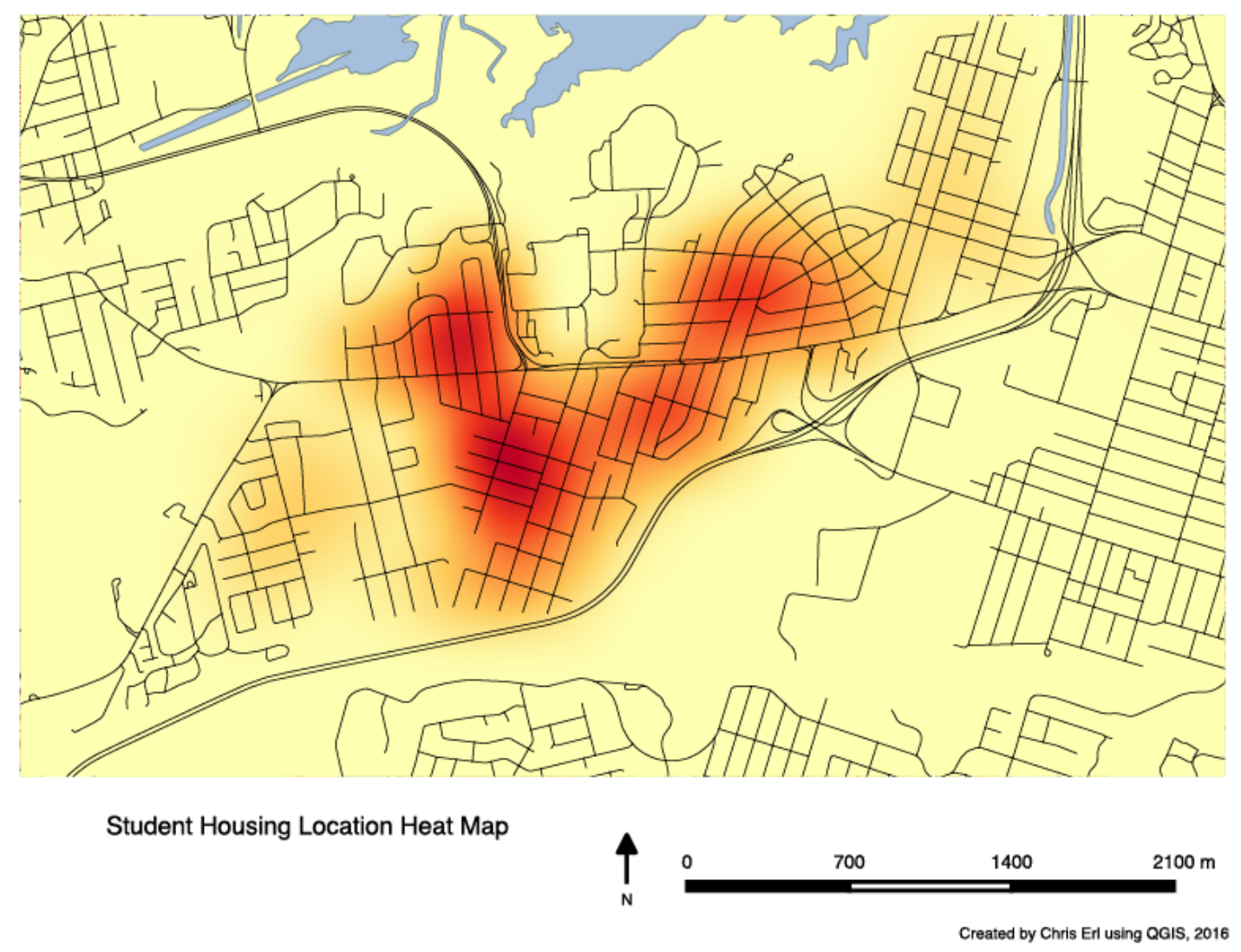

Figure Eight: Student Housing Location Heat Map in the Westdale/Ainslie Wood Area

When the 755 student houses were mapped, a clear clustering became apparent. Student houses were mainly concentrated in the eastern segment of Ainslie Wood North between Main Street West and Sanders Boulevard, between Leland Street and Emerson Street north of Whitney Avenue in Ainslie Wood East, and between Main Street West and Sterling Street in the southwestern corner of Westdale South. The main concentration of student housing was within 800 metres, or a 10minute walking distance, of any of McMaster's main campus entry points. 
After the clustering of student homes was established, each neighbourhood and street was analyzed independently. Using the detailed information collected from each listing and available Open Data files from the City of Hamilton, the 114 streets of Ainslie Wood and Westdale were analyzed based on the number of single detached residences, semi-detached residences, and townhomes with addresses listed on those streets compared with the number of identified student homes. This can be represented by the equation:

$$
\frac{\text { (number of identified private market student rentals) }}{\text { (number of student residences) }} * 100=\% \text { of student homes }
$$

To make analysis simpler, the City of Hamilton's 'planning unit' designation was used to further classify geographic areas. These planning units correspond closely to the established neighbourhood boundaries of the city.

Excluded from analysis were Main Street West and the segment of King Street West covered by the Westdale Business Improvement Area (BIA). Main Street West serves as a major thoroughfare with only a small number of single detached homes that face onto the street and the only single detached homes in the Westdale BIA have been converted for alternate uses.

Of the streets analyzed, 23 were comprised of over $30 \%$ student rentals. 19 streets were between $20 \%$ and $29.99 \%$ student homes, while a further 24 streets fell between $10 \%$ and $10.99 \%$. 47 streets fell below $9.99 \%$.

Within the 23 streets on which there were over $30 \%$ student rentals, seven streets crossed the $50 \%$ mark. Two of those crossed $60 \%$. The seven that sat over $50 \%$ were unequally divided between Ainslie Wood West, Ainslie Wood East, and Ainslie Wood North, with four of those streets falling within the latter neighbourhood (See Appendices Seven to Twelve for a visual representation of this distribution). 
With figures ascribed to certain streets, it becomes possible to open discussion regarding balance in communities and thresholds over which streets and communities become unbalanced. The housing tenure of students is uneven, as students are more flexible in their demands, affording them the opportunity to move frequently (Rugg, Rhodes, and Jones, 2002). This inconsistency, combined with students traveling to their parental homes, for work, or generally elsewhere during exam periods or over seasonal breaks, leaves student residences infrequently occupied. This uneven occupation can make student homes more prone to burglary, lack of regular property maintenance, and deny the community a core of constituents that can exert political pressure on elected officials or other institutions if the need arises (Kenyon, 1997).

\section{Creeping Studentification}

As Kenyon (1997) noted, "images of the home and neighbourhood are often imbued with expectations of privacy, personal choice, control, and security within a defensible space." Challenges to these perceived notions of what home and community should resemble are met with fierce opposition. Kenyon's research pointed to a perception of students as a separate group within the community that cannot be integrated and that will have a negative impact on the physical and perceived structure of the community. This sentiment has been echoed by supplementary research that establishes students as a distinct grouping, with perceptions of students ranging from 'a community within a community' to 'unwelcome outsiders' who will be unable or unwilling to better integrate with the community in which they find themselves living for a distinct period in their lives (Munro, Turok, and Livingston, 2009).

Some selections from letters to the editor published by the Hamilton Spectator from those identifying as residents of Westdale and Ainslie Wood provide a strong indication that Kenyon's hypothesis is correct in the context of McMaster students and the surrounding community: 
“The students are young and very immature." (Scapinello, 1999)

"We need a crackdown on drunken students, those who litter like pigs, ride bikes up and down the sidewalks not caring who is in the way." (Berk, 2003)

"...some students believe they have the right to party and make noise at all hours because this is part of university life." (Ennis, 2006)

“...the students... are short-term guests in the community." (Peters, 2006)

"If the city would monitor the actions of these students and show them some consequences for their actions, perhaps they wouldn't have an "attitude" as mentioned by a resident who was given the finger for looking out her window." (Northcott, 2007)

"I believe it should be made clear to all university students that they are to be responsible and respectful neighbours. To do otherwise should result in possible expulsion from the university. Easy for [former] university president Peter George -he doesn't have to live in the student-infested neighbourhoods." (Robinson, 2007)

The language used, comparing students to 'pigs', referring to them and 'guests' and neighbourhoods as 'student-infested' provides a strong indication as to the lack of community cohesion in these neighbourhoods.

Westdale was the point of origin for a majority of the letters and a substantial portion of the vocal opposition, with only a select few pieces coming from residents of Ainslie Wood. Only three of the 25 streets with the highest percentage of student housing were in Westdale, though the events related to student housing that elicited the strongest reaction from local media and residents, such as the relocation of The Phoenix and the protests surrounding perceived conversions, occurred in that particular neighbourhood. 
Westdale serves as the geographic origin of oppositional activism as the events that signal change in the neighbourhood are more expressly felt in areas that sit below a saturation threshold. This is likely due to a perception amongst residents of Westdale that their street may be the next to become unbalanced. It can be asserted that, due to the presence nearby of student streets, residents perceive a 'creeping studentification' threatening their neighbourhood.

Sage, Smith, and Hubbard (2012) discuss a community in the United Kingdom that began to mobilize against student housing after the local university began selling some of the housing stock it owned and operated in the area to private developers. The community, Brighton's Elm Grove, contained Lower Super Output Areas, roughly equivalent to Canadian Census Dissemination Areas (CDAs), that were made up of between 13\% and $42 \%$ students. The authors note that Elm Grove was characterized by a significant percentage of private renters when compared with Brighton as a whole.

Organized community opposition aimed at student housing began in 2008 , with residents regularly writing letters to their local paper and establishing community groups aimed at presenting a unified front against what residents saw as a community in danger of becoming unbalanced (Sage, Smith, and Hubbard, 2012).

The case of Westdale mirrors that of Elm Grove. Trigger events sparked community outcry as residents felt their way of life threatened by an oversaturation of student housing. The reaction of community members follows the same general trajectory, characterized by prolific letter writing campaigns and the establishment of groups focused on addressing the issue of student housing. The housing characteristics of Westdale are similar to those of Elm Grove as well, with the proportion of renters in some CDAs in both Ainslie Wood and Westdale sitting well above the 


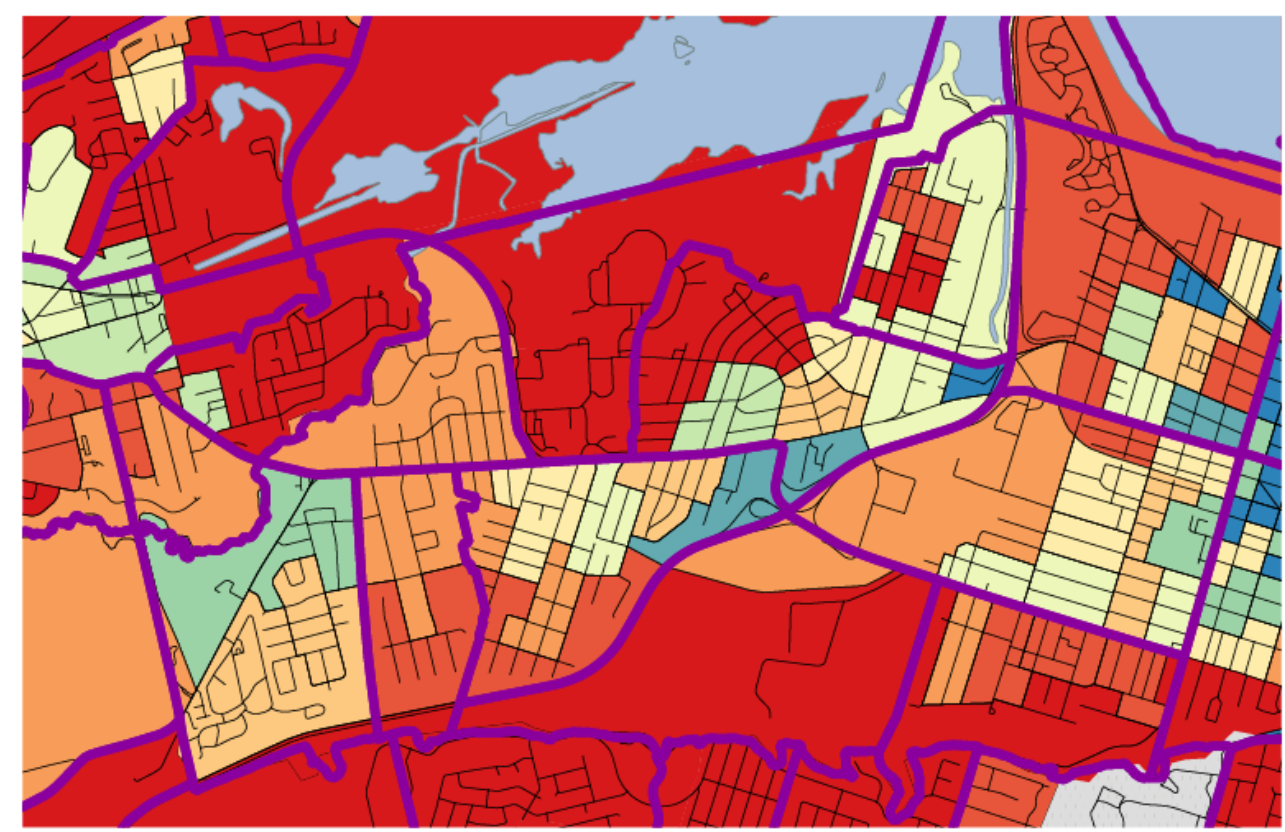

Percentage of Renters by Census Dissemination Area in West Hamilton
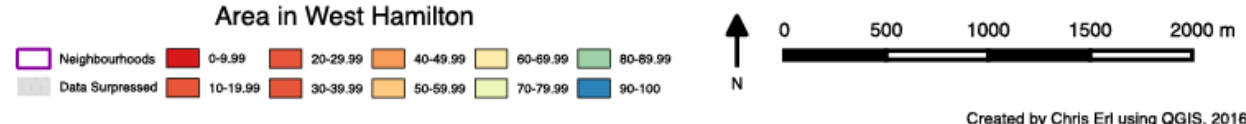

Figure Nine: Percentage of Renters per census dissemination area in West Hamilton

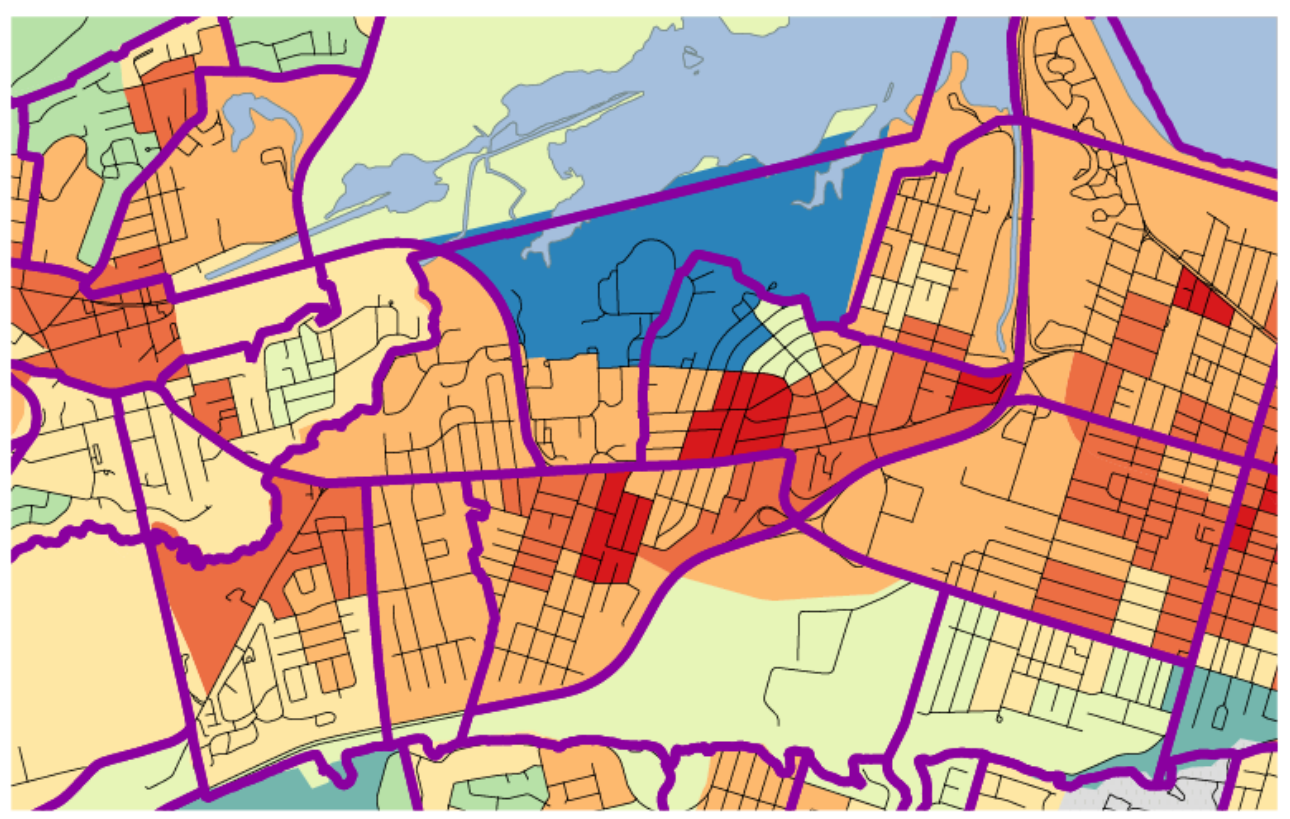

Median Household Income by 2011 Census Dissemination Area

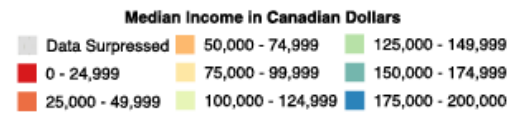

$\square$ Neighbourhoods

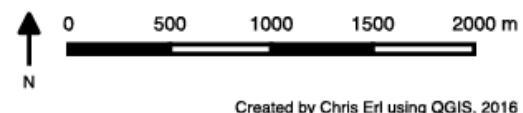

Figure Ten: Median household income per census dissemination area in West Hamilton 
Hamilton average of $31.63 \%$ (Figure Seven). ${ }^{2}$ The distribution of ownership was uneven, though, as the 2011 Census indicated that Westdale was home to pockets that consisted of high home ownership interspersed with areas where renters constituted the majority of residents. Additionally, the same census found that income rates varied across the neighbourhood, with some CDAs falling well below the Hamilton median average of $\$ 60,259$ bordering the CDA with the highest median income in Hamilton (Figure Eight).

Residents of Westdale, maintaining varying levels of income and housing ownership, have likely perceived the spread of student housing as a threat to their community and perceptions of home. As there is a correlation between low rates of housing ownership, lower median incomes, and areas where student housing is prevalent, the opposition of residents can be viewed as an attempt to maintain stability in the face of a potential unbalancing of their community.

\footnotetext{
${ }^{2}$ This is based off a Census Dissemination Area analysis of the 2011 National Household Survey (NHS). It is important to note that, due to changes made to the NHS by Canada's $41^{\text {st }}$ Parliament, the 2011 edition has varying levels of reliability. The census dissemination areas examined had a Global Non-Response Rate of between $8.7 \%$ and $65.3 \%$. This information should be updated with new data from the 2016 NHS which will likely be more reliable due to further revisions by enacted by Canada's $42^{\text {nd }}$ Parliament.
} 


\section{Recommendations}

If tensions occur because residents in established communities observe the studentification of adjacent streets and neighbourhoods and believe such a shift to challenge their preconceived notions of home and community, it becomes necessary to seek strategies to rebalance communities. Students, as both previous research and unique data collection have indicated, have expressed a preference for living near their university campuses, making the existing single detached housing stock in near-campus communities appealing to investors seeking to rent to a captive and relatively undemanding market (Charbonneau, Johnson, and Andrey, 2006).

Rugg, Rhodes, and Jones (2002), in their analysis of the student rental market in the United Kingdom, confirm the assertion that students are incredibly flexible when it comes to their rental accommodation and that landlords tailored their businesses to students. As such, it can be asserted that, in the absence of effective regulation, municipal abrogation to the free market has enabled the unbalancing of communities. Preventing an overconcentration of student accommodation and the conflicts that arise due to the resulting unbalancing of communities requires an even distribution of private-market rentals. In this respect, the planning profession is limited in what it can recommend.

To address this unbalancing, it may be necessary to examine planning strategies from other countries or advocate for unique solutions. These solutions must perform some key functions, namely:

- Better monitor the private-market rental situation in near-campus communities,

- Encourage universities to take an active role in the provision of student housing, and

- Allow for a variety of housing tenures to be represented. 


\section{Better monitor the private-market rental situation in near-campus communities}

Ensuring the issue of student housing is better understood by municipalities ensures that the issue can be studied at length in the future. Through further study, planners and municipal officials can develop effective strategies surrounding an even distribution of student accommodation and rebalancing of communities. In the United Kingdom, the issue of student housing leading to unbalanced communities led lawmakers to strike a committee to address the phenomenon. The All-Party Parliamentary Group for Balanced and Sustainable Communities sought to address the issue, going to far as to examine the planning regime in the United Kingdom and the potential to develop legal solutions to over-concentrations of student housing (Hubbard, 2009).

Canadian municipalities should take steps to investigate the situation in their own jurisdictional boundaries. Each municipality and near-campus community is unique, while maintaining some key similar characteristics. Establishing a foundation on which study can occur and information can be shared will be key to ensuring solutions will be developed in the future.

Municipalities can investigate licensing systems to keep an effective record of student accommodation. London, Ontario, maintains a licensing system that specifically targets privatemarket rentals. Landlords who rent four rooms or fewer, or had added rooms to their property without increasing the size of their building's footprint since 1993, are covered under the licensing by-law that came into effect in 2009 (Sher, 2009).

Alternatively, municipalities and universities can work in tandem to establish voluntary licensing systems that will give landlords preference when advertising through universitysanctioned media, while still affording municipalities some idea as to the location of student accommodation. Though not a widely considered option, there is precedent for such a program. At present, the City of Kingston, in conjunction with Queen's University, operates the Voluntary 
Inspection Program, or VIP, initiative. Free of charge, the program offers longer by-law compliance timelines and strives to operate as a proactive, rather than a complaint-based, program. Landlords who subscribe to the VIP program are given a certification that they are allowed to use when advertising to potential renters (City of Kingston, 2015).

For its part, the Municipal Property Assessment Corporation (MPAC) can alter how it assesses properties to provide municipalities with information surrounding student housing. Presently, MPAC maintains a residential property code 366 , which is listed as "Student housing (off campus) - residential property licensed for rental by students," (Municipal Property Assessment Corporation, 2016). As this designation is applied to licensed student housing, it is not accurately applied to every private-market rental aimed at students. A more liberal usage of this designation will assist municipalities in gathering information on the location of student housing.

Encourage universities to take an active role in the provision of student housing

Another strategy to address community tensions is for municipalities to encourage universities to assume a more active role in providing housing. There is some indication that universities are moving back toward the provision of on-campus residence in a way that blends an emphasis on highest-and-best uses where space is in short supply and innovative mixing of uses to avoid the characterization of residence as 'institutional' and 'sterile'. In 2015, McMaster announced a new 500-bed residence would be constructed on the north side of their campus that would incorporate study and classroom space in an attempt to blend uses and provide for a wide array of students (Thompson, 2015). With encouragement and planning support from municipal authorities, universities may find the construction and provision of on-campus residence a realistic option once more. 
Alternately, universities can become active in the single-detached rental market, purchasing homes and providing accommodation along the lines of that already provided by the private market. There is some precedence for this in the United Kingdom, as was indicated during the discussion point on the Elm Grove community in Brighton (Sage, Smith, and Hubbard, 2012). The University of Ottawa, which has long struggled with the provision of residence and a tense relationship with the neighbouring Sandy Hill community, owns a number of converted singledetached homes that are rented to students. These houses maintain similar characteristics to the private-market rentals provided in the community, but are maintained by the university, which addresses the community concern about absentee landlords. Additionally, the student tenants of these homes are bound by the university's regulations regarding behaviour in residence, addressing another concern many residents have with student neighbours. The University of Ottawa even markets these residences by highlighting their reliability, indicating the the houses are, "Geared towards students registered in 2e year and up [and] are perfect for students who are looking for an off campus experience, yet dealing with a trusted landlord (the University)," (University of Ottawa, 2016).

Allow for a variety of housing tenures to be represented

With the established resident perception that students are 'guests' and 'outsiders' and the impact that inconsistent housing tenure has on the social dynamics of a community, it is necessary for planners and municipal authorities to seek strategies that will provide for more diversity in the field of housing tenure. Past research has indicated that, even when compared with other populations deemed to be mobile, students will still move more frequently (Munro, Turok, and Livingston, 2009). Providing for a community where long-term residents and live alongside medium-term renters and short-term student tenants is one strategy to rebalancing communities. 
Better promoting mixed-use neighbourhoods can have this effect. Encouraging a diversity of housing types, from single-detached and semi-detached, to row houses and apartments, in addition to mixed-use developments along major corridors will encourage a diversity array of residents to establish themselves in near-campus communities. Indeed, the potential for mixed-use developments to promote a diversity of housing tenure types is being explored as a possibility in Canadian cities for improving community mixture and greater social equality (Grant, 2002). 


\section{Conclusions/Further study}

This analysis of the situation in near-campus communities is a brief overview of an extremely large and complex issue. Student housing is different from jurisdiction to jurisdiction, from campus to campus. While some municipalities have been dealing with the issue of student housing and unbalanced communities for decades, other cities do not find themselves facing as complicated an issue. Indeed, this is an issue that impacts a particular kind of municipality disproportionately. Rugg, Rhodes, and Jones (2002) found a distinct connection between city size and the vibrancy of the private-market rental sector, with large municipalities such as London maintaining a far smaller single-detached student housing market than medium sized cities, such as Belfast or Cardiff.

It would be pertinent to examine the student housing situation in large municipalities across Canada, specifically examining Vancouver, Calgary, Toronto, and Montreal. Additionally, a more detailed and cross-jurisdictional analysis of major university centres nationwide would add to the existing understanding of the student housing situation in near-campus communities.

A detailed comparative analysis between bylaw complaints, such as complaints about neglected properties, noise, or charges for public drunkenness, and the locations of unbalanced streets would aid in pressuring lawmakers and planners to enact changes to the current planning regime that responds to challenges placed on communities by the market. Additionally, as was noted in the previous section, a comprehensive database of the location of student houses on a municipalityby-municipality basis would similarly aid in further study. Such a database would require the assistance of universities and the participation of landlords, either willingly or mandated through law.

Finally, a more rigourous and detailed elaboration on the idea of 'student streets' will be helpful in adding to the existing understanding of community dynamics. As student streets were posited 
to serve as the central feature in unbalancing communities and leading nearby residents to perceive the presence of such streets in their communities as a sign of 'creeping studentification', a more thorough understanding of the idea of 'oversaturation thresholds' and 'student streets' is essential.

Student housing is a broad, complex, and dynamic field that requires more research to alleviate pressures on residents, students, and municipalities caused by an uneven distribution of privatemarket rentals and a lack of meaningful regulation.

The call put forth in the concluding lines of Room to Learn is as pertinent today as it was in 1968, and must be reissued to inspire the academy to look inward and not fear a needed element of self-analysis.

"Answers will not come from any single source. Administrators, faculty, students, governments must continue with the enquiry. We need more thought, more sound research, more experimentation," (Sears, 1969). 

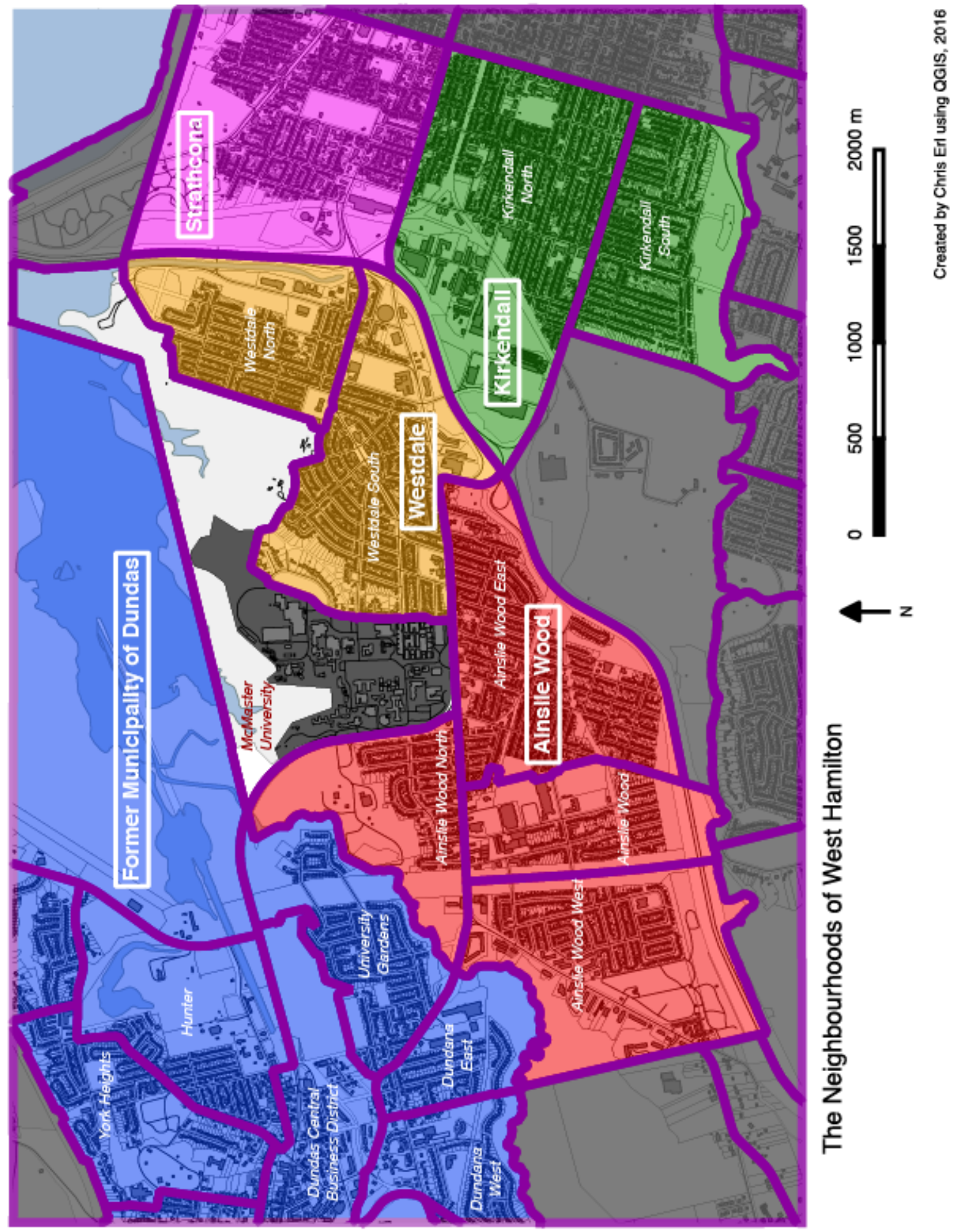

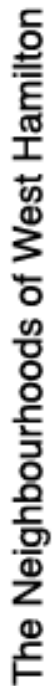


Appendix Two: Residences of McMaster University

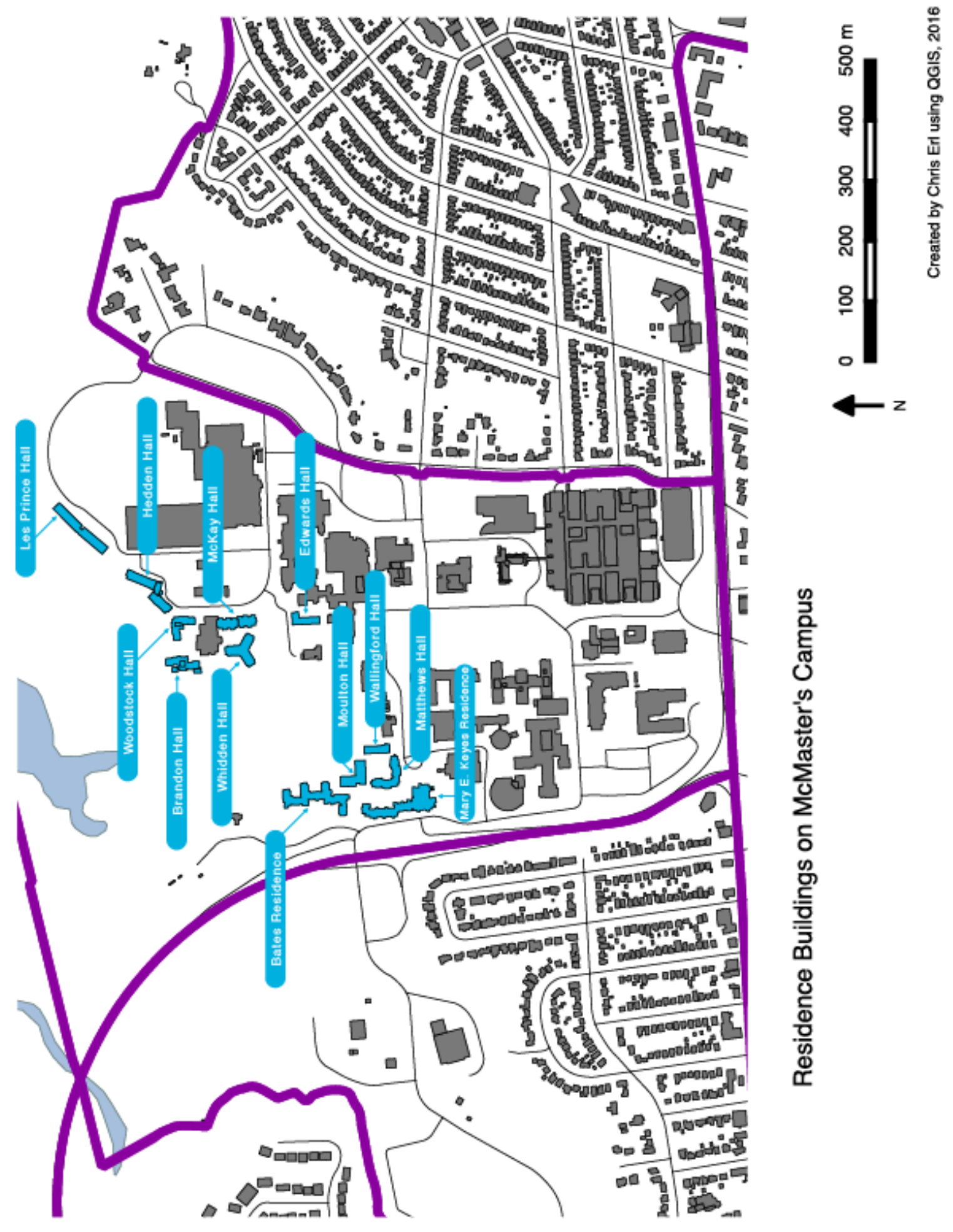


Appendix Three: Purpose-built Student Housing in Hamilton

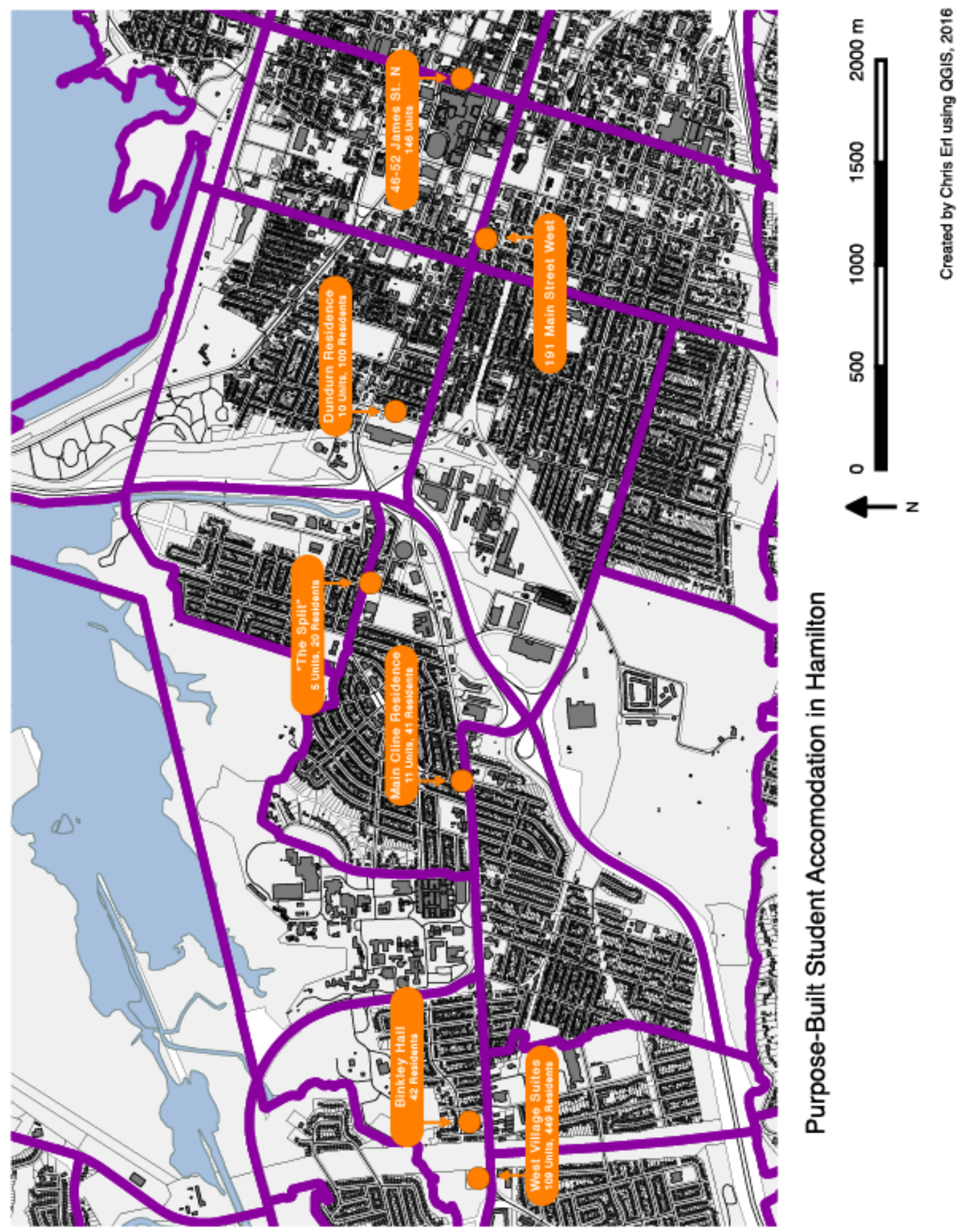


Appendix Four: Identified Private-Market Single-Detached Student Rentals

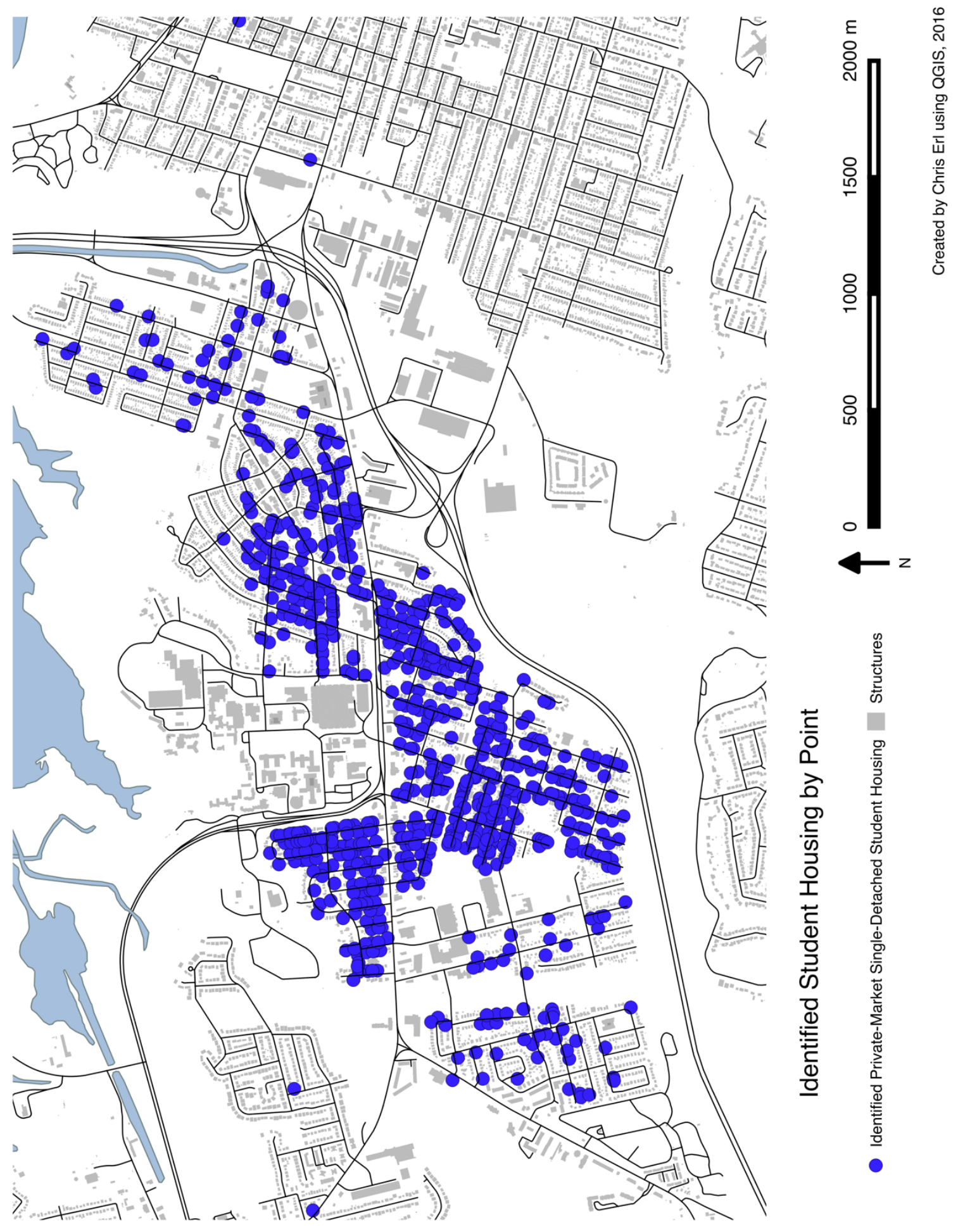


Appendix Five: Walking Distance

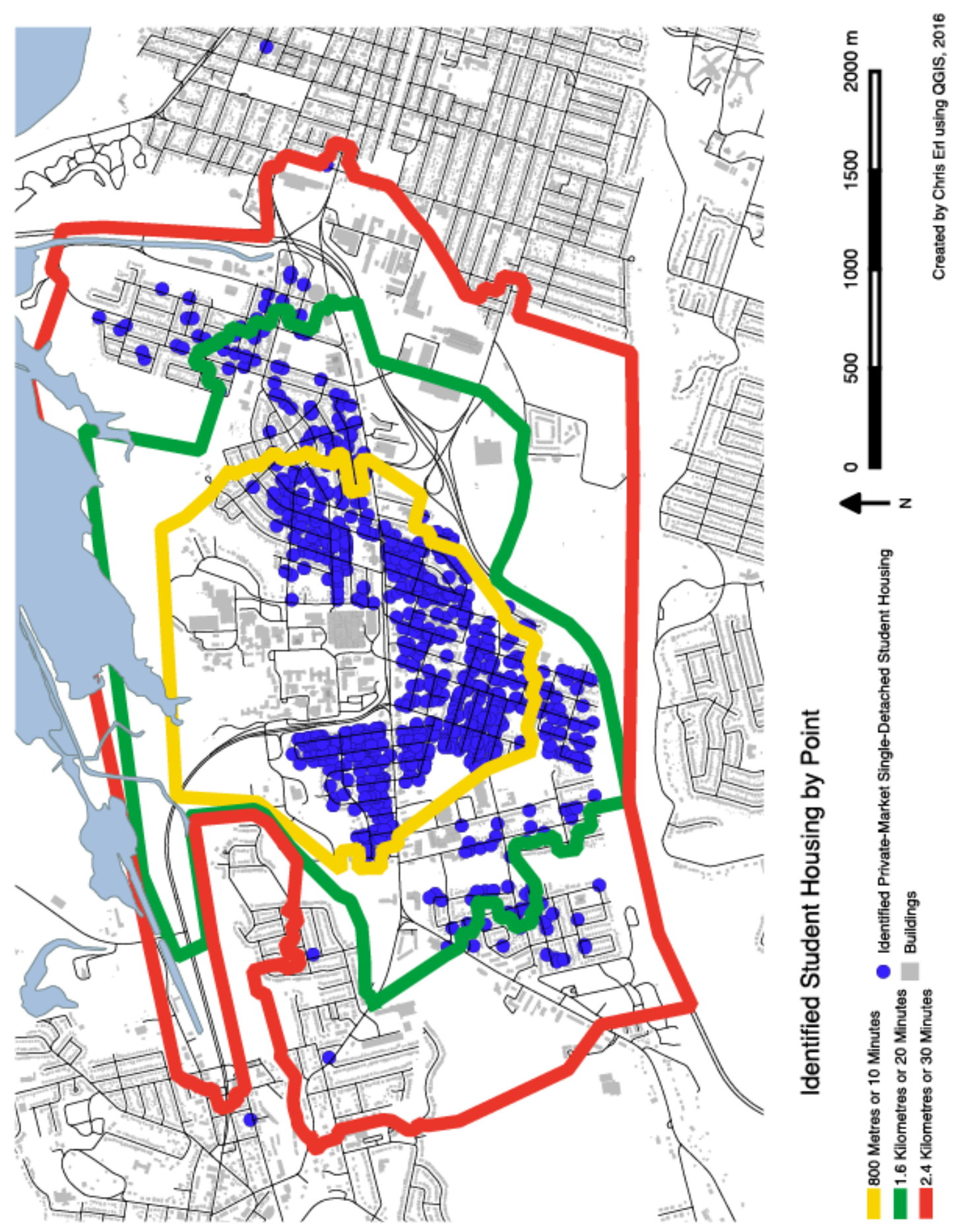


Appendix Six: Student Housing Heat Map

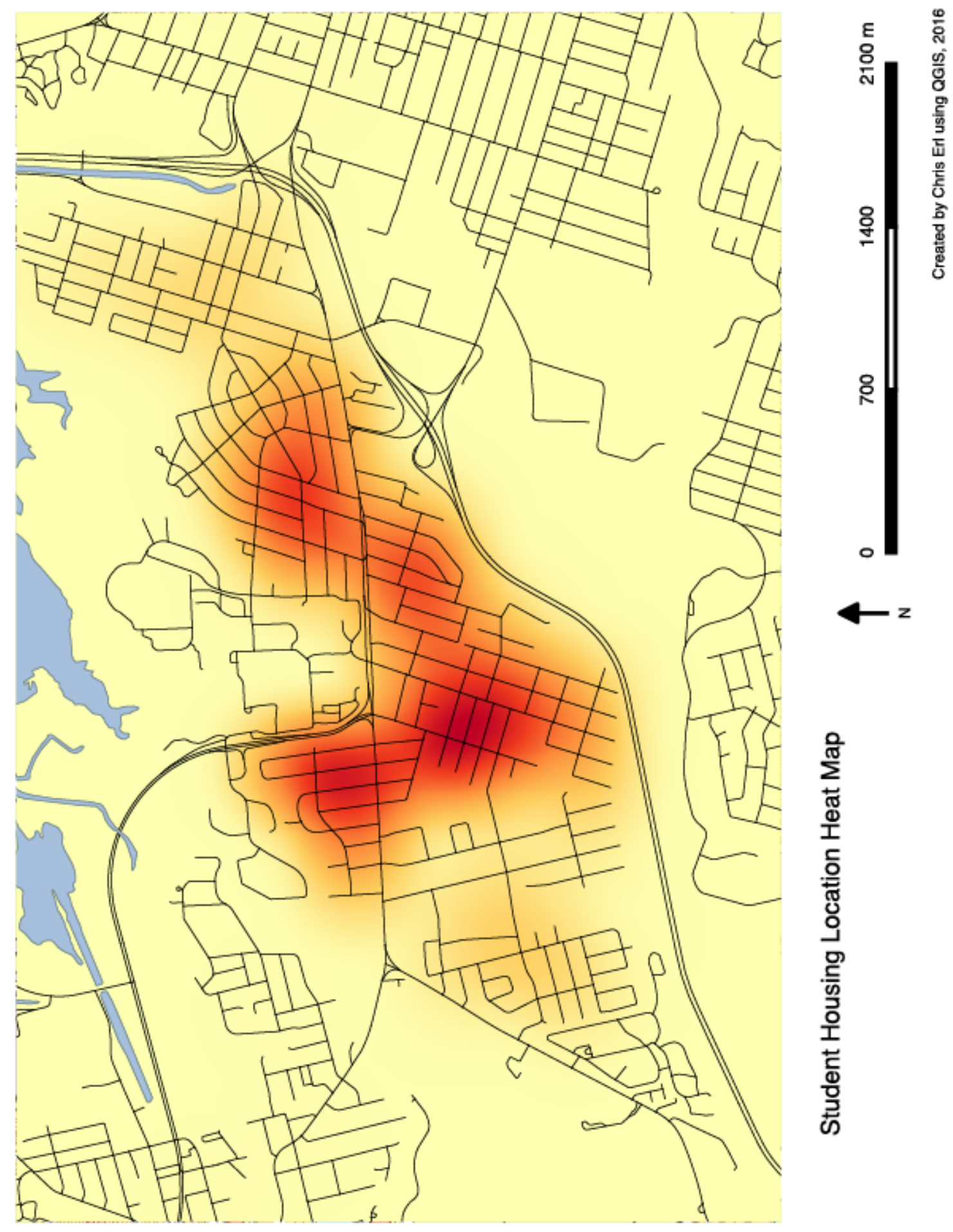


Appendix Seven: Ainslie Wood West Student Streets
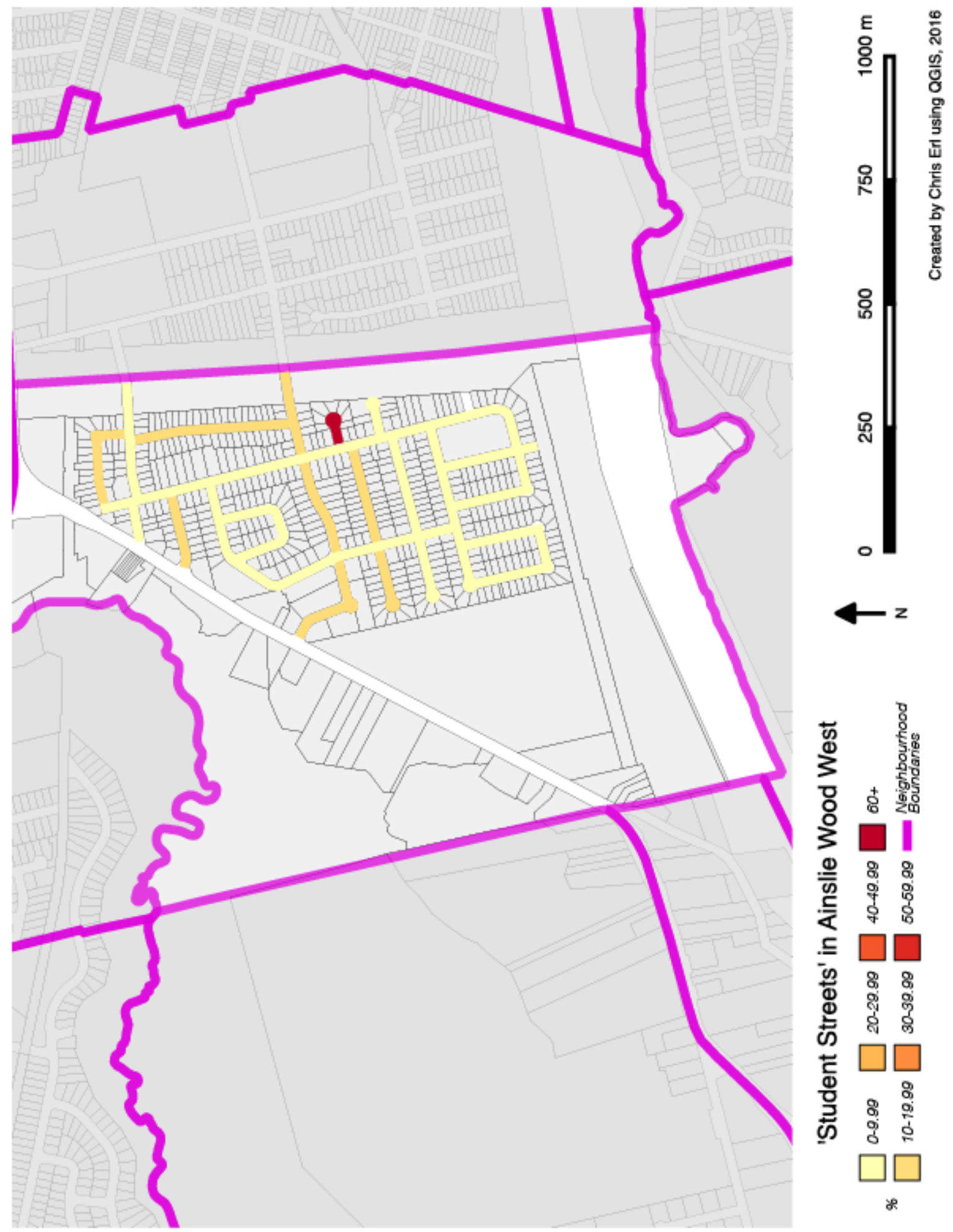
Appendix Eight: Ainslie Wood Student Streets
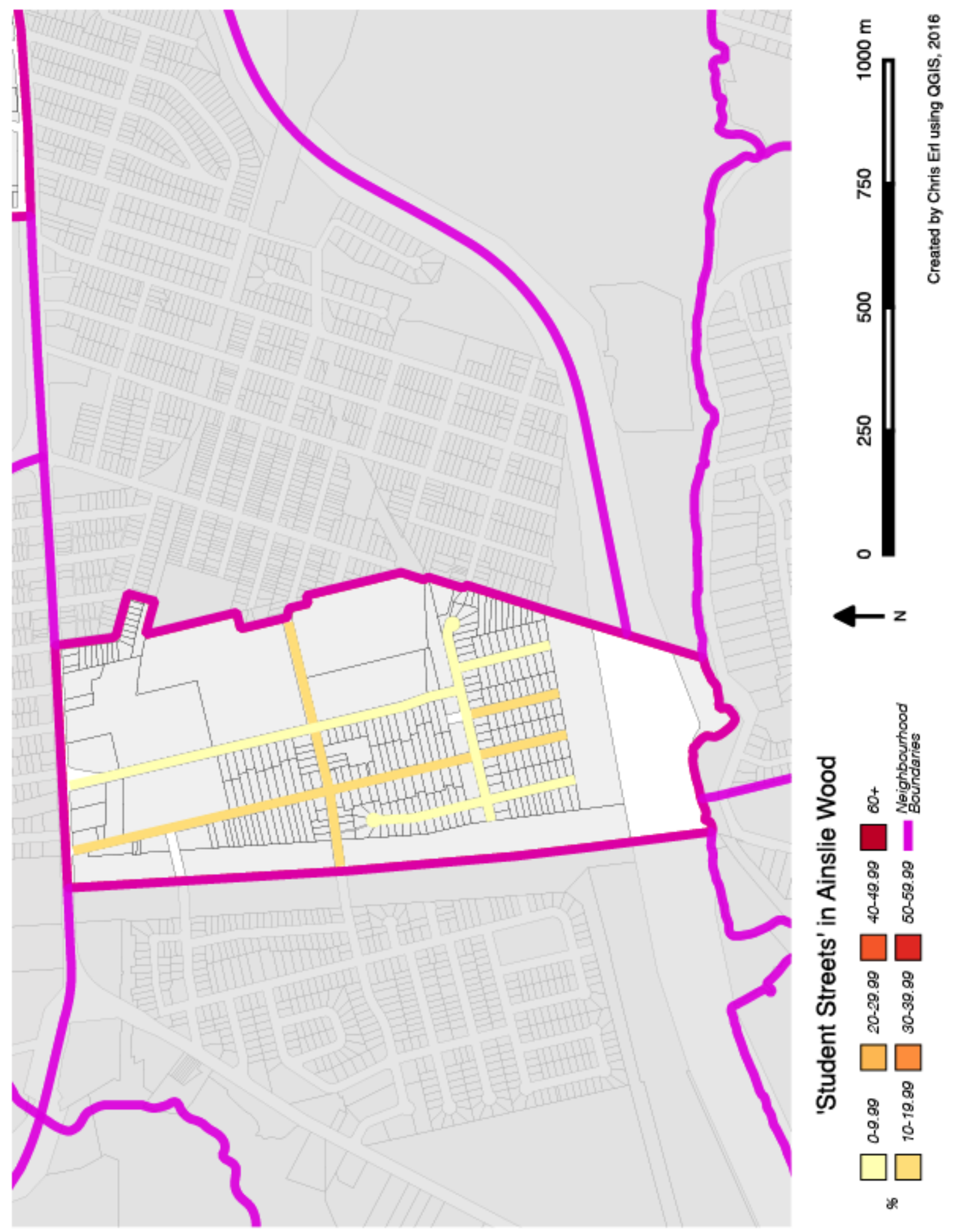
Appendix Nine: Ainslie Wood East Student Streets
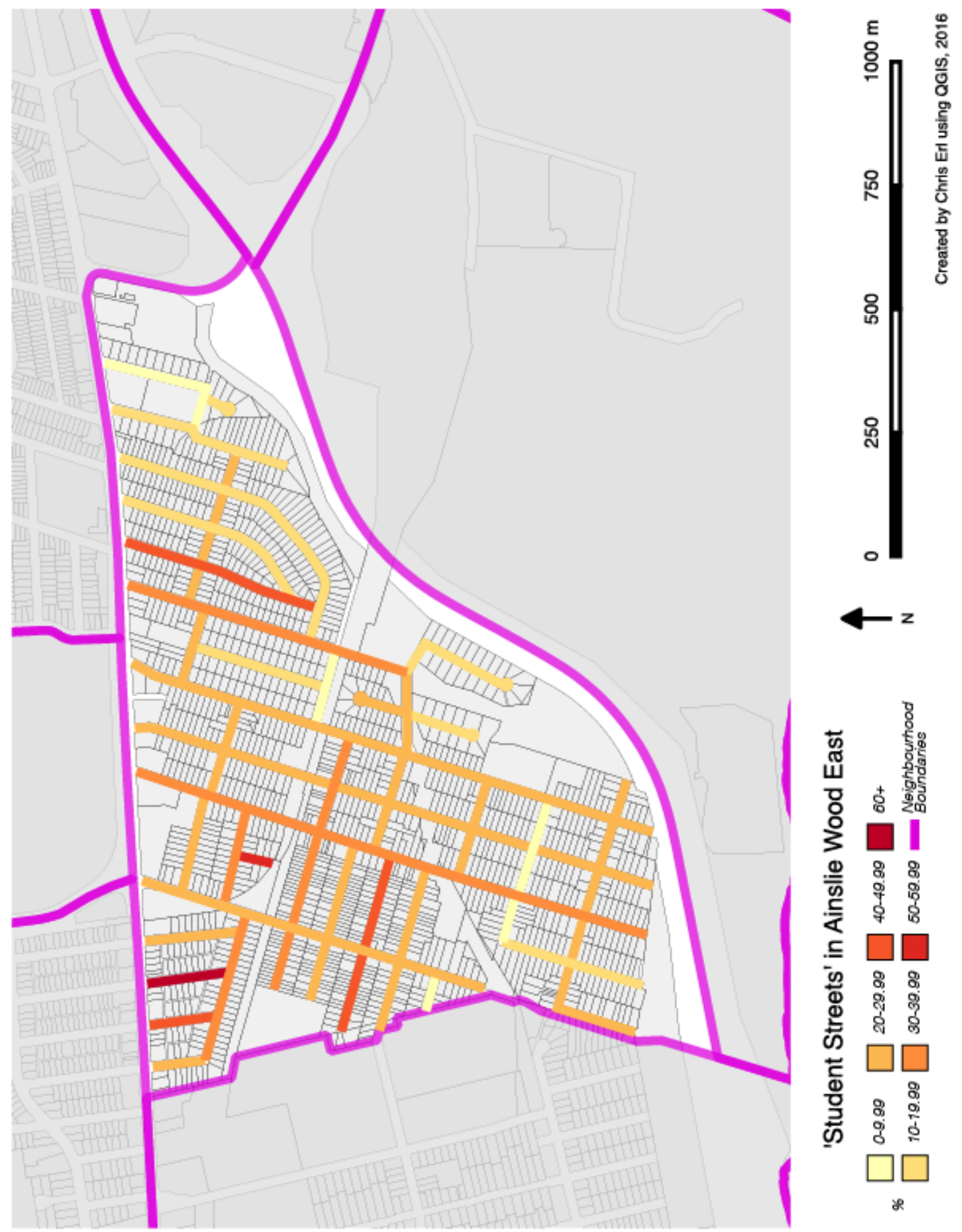
Appendix Ten: Ainslie Wood North Student Streets
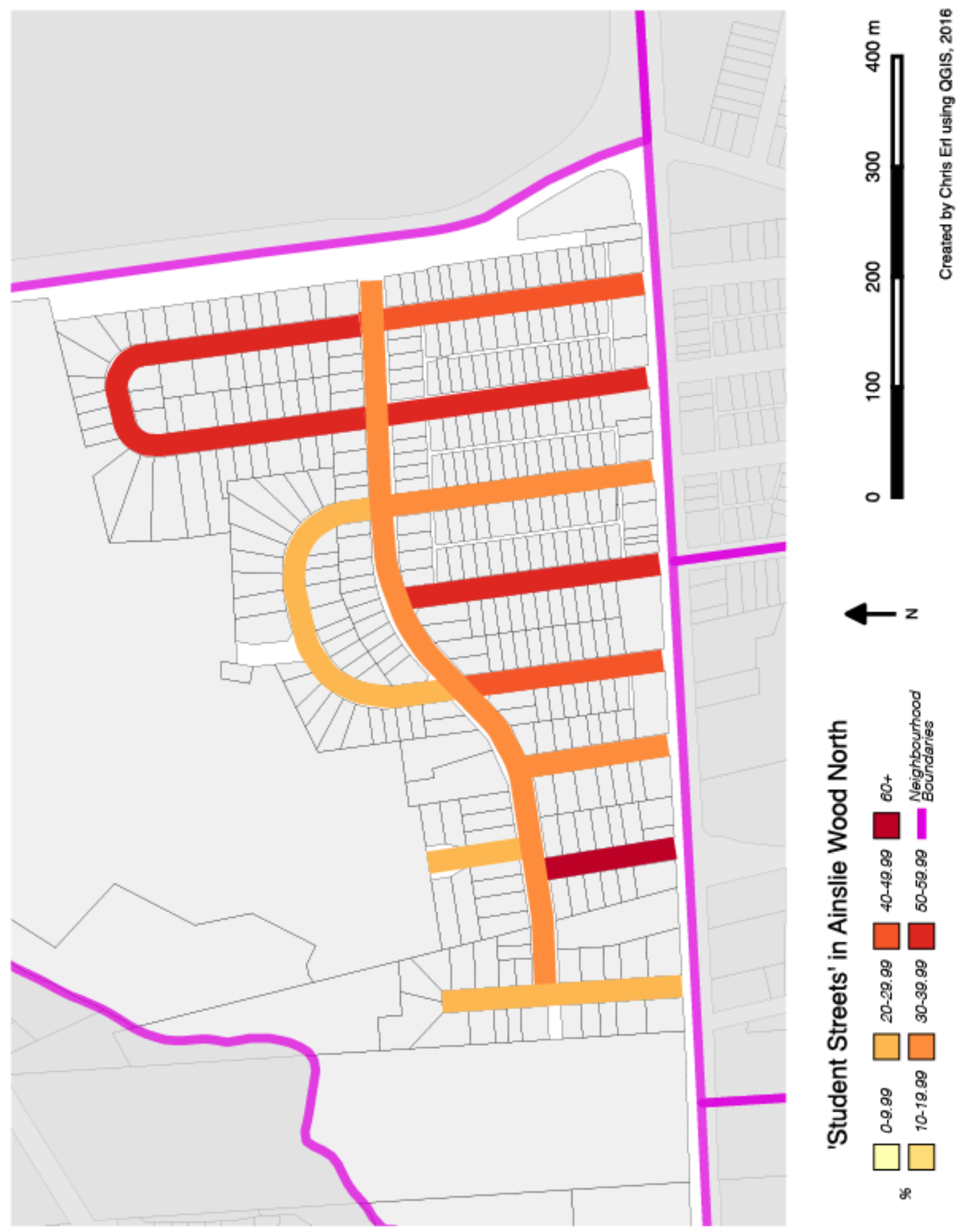
Appendix Eleven: Westdale South Student Streets
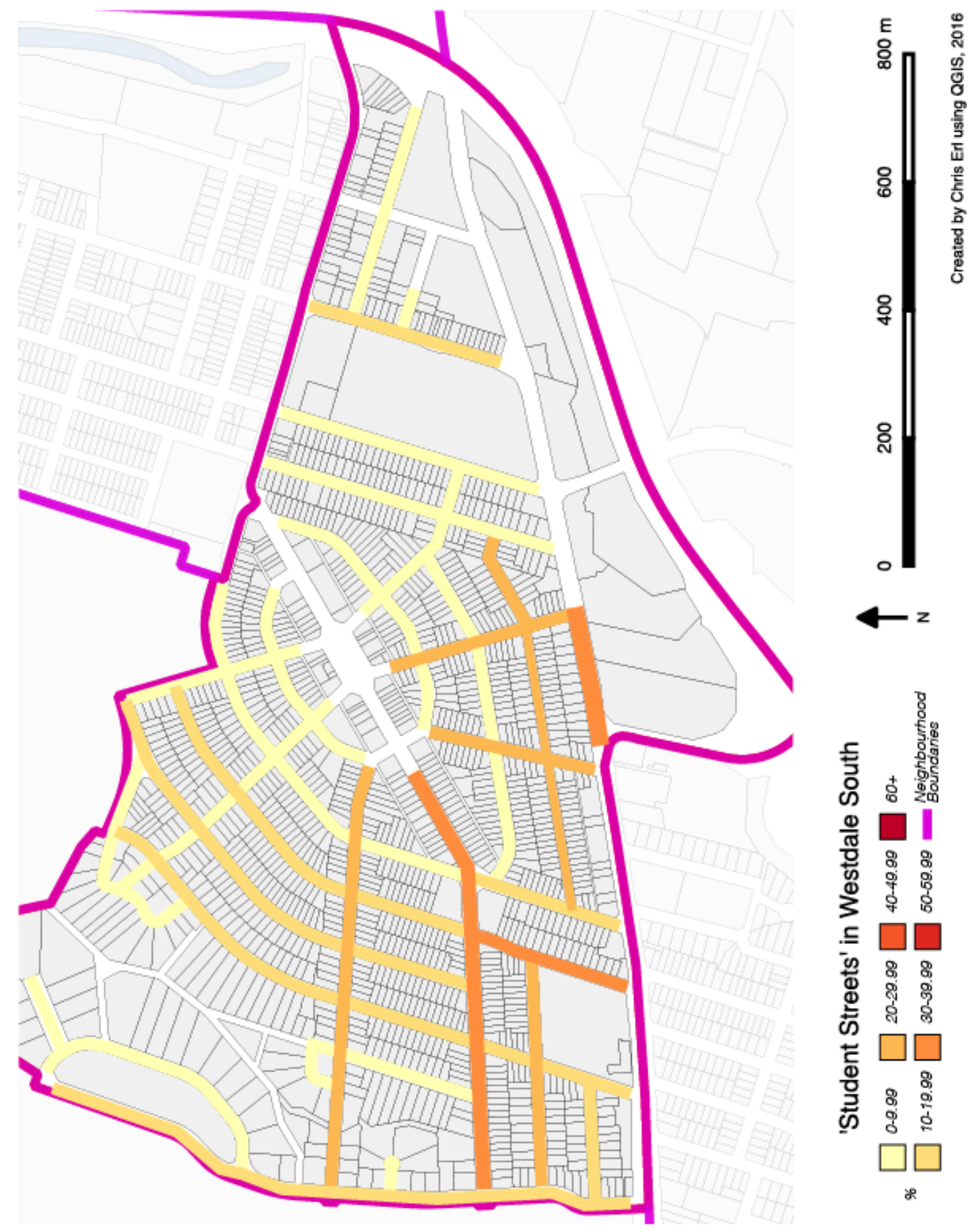
Appendix Twelve: Westdale North Student Streets
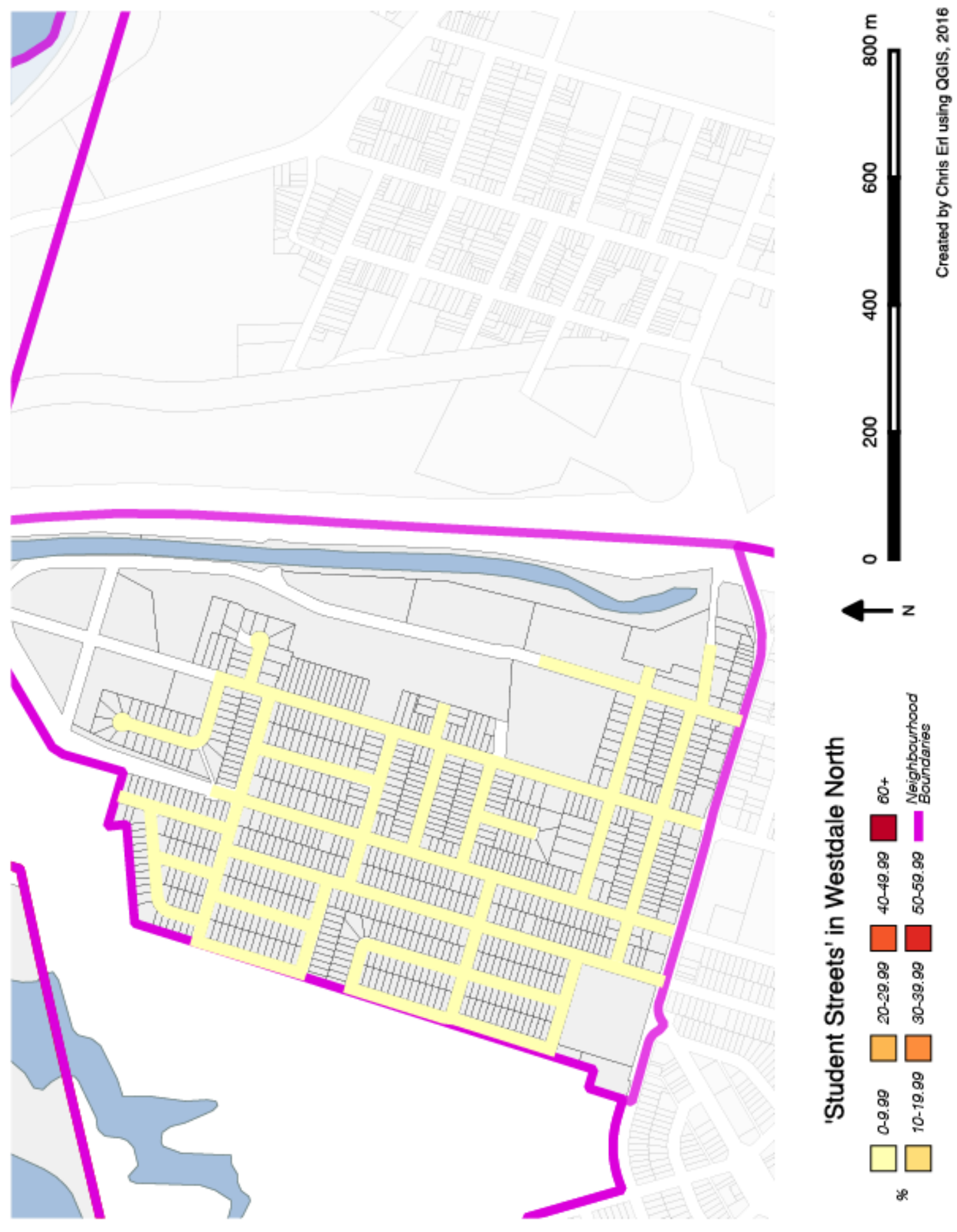
Appendix Thirteen: Land Uses in Ainslie Wood

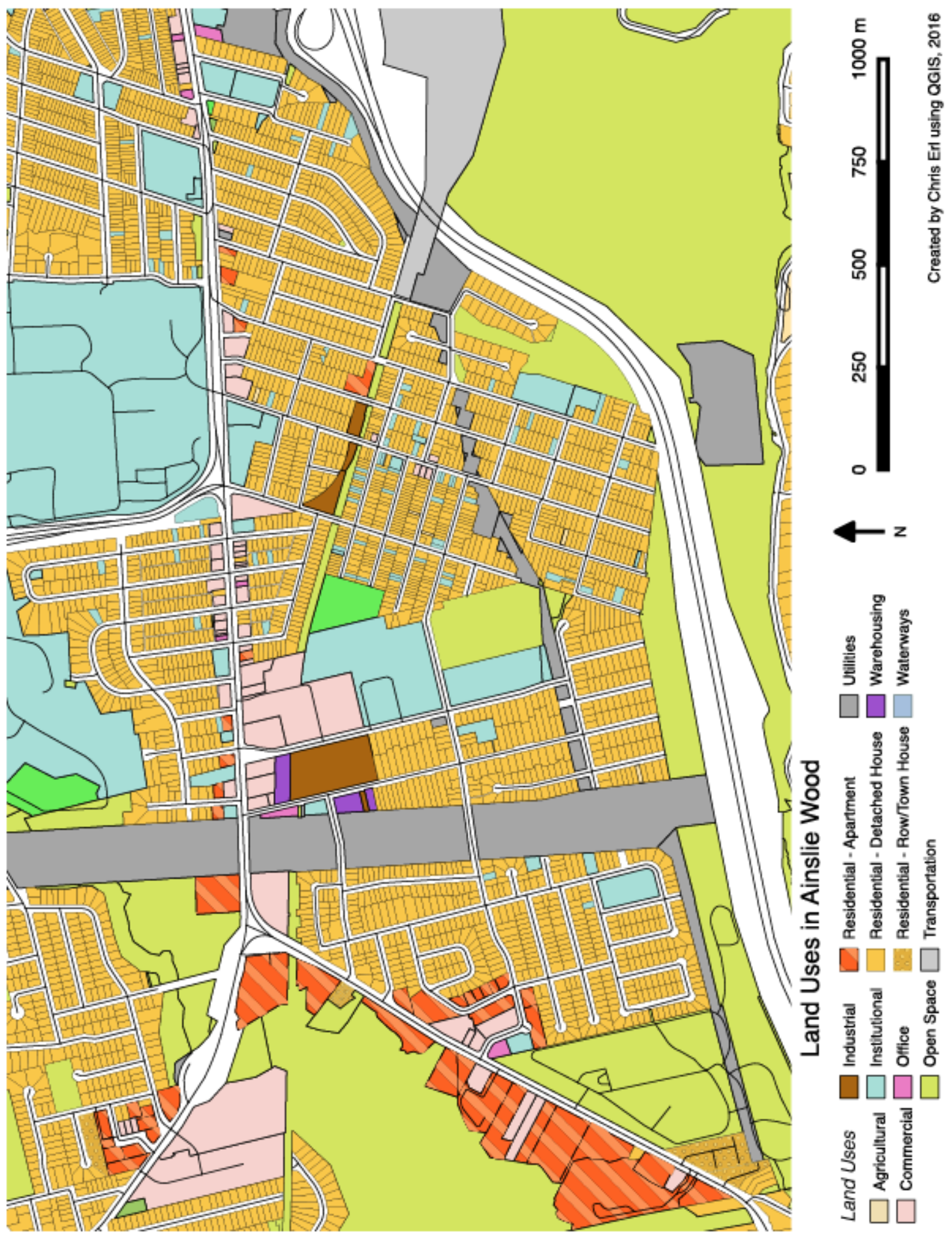


Appendix Fourteen: Land Uses in Westdale

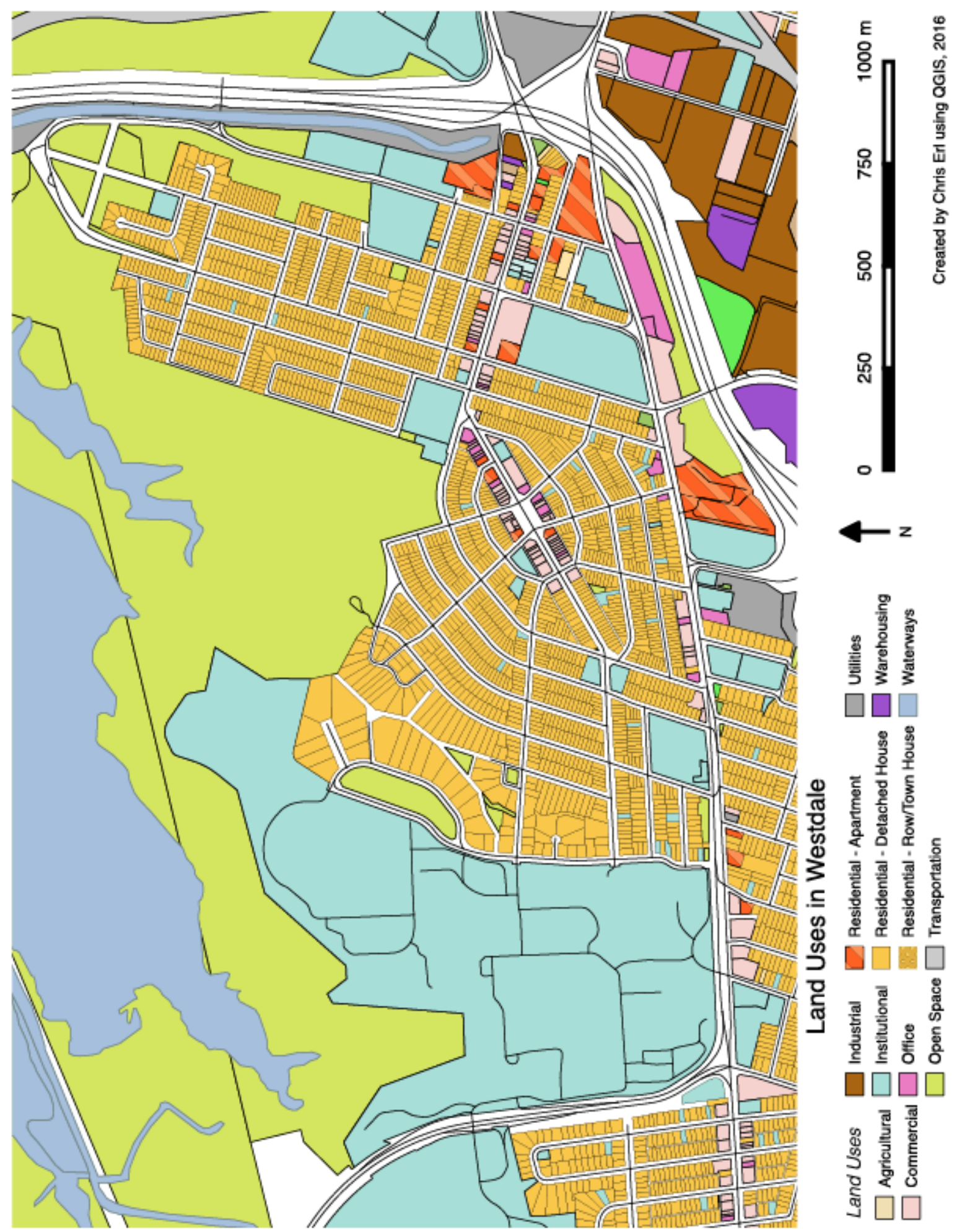




\section{Sources}

Anslie Wood Community Association (2015). "Re: UHOPA - 15 - 017, ZAC - 13 - 027," City of Hamilton Planning Committee Correspondence, August 4, 2015.

Berk, Daniel (2003). "Letter: Let's have some control," Hamilton Spectator, August 27, 2003, pp. A12.

Bradshaw, James (2014). "McMaster to crack down on drinking, orientation activities," Globe and Mail, April 20, 2014.

Charbonneau, Pamela, Laura C. Johnson, and Jean Andrey (2006). "Characteristics of University Student Housing and Implications for Urban Development in Mid-sized Cities," Canadian Journal of Urban Research vol. 12, no. 2, pp. $278-300$.

City of Hamilton (2013). Urban Hamilton Official Plan: Ainslie Wood/Westdale Secondary Plan - Land Use and Cultural Heritage Landscapes map. Hamilton: City of Hamilton Planning and Economic Development Department.

City of Kingston (2015), "Report to Planning Committee - Report Number PC-15-031," June 18, 2015, retrieved from the City of Kingston's website:

https://www.cityofkingston.ca/documents/10180/9727342/PLN_A1115-15031.pdf/8fbbf272f5f0-4163-aea0-d4086f90fd7d

CityHousing Hamilton (2014). Student Apartments Pamphlet. URL retrieved from: http://www.cityhousinghamilton.com/userfiles/file/LookingForHousing/Trifoldmain_student_2014.pdf

Cummings, Madeline (2014). "High Noon in the Hammer: How Hamilton Has Defined Arkells," Chart Attack, August 6, 2014, URL retrieved from:

http://www.chartattack.com/features/2014/08/06/high-noon-hammer-hamilton-defined-arkells/

Devlin, Ann Sloan, et. al (2008), "Residence Hall Architecture and Sense of Community: Everything Old Is New Again,” Environment and Behavior vol. 40, no. 4, pp. 487 - 521.

Domonoske, Camila (2014). 'Segregated From Its History, How 'Ghetto' Lost Its Meaning,' CodeSwitch on NPR, April 27, 2014, URL Retrieved from:

http:/www.npr.org/sections/codeswitch/2014/04/27/306829915/segregated-from-its-historyhow-ghetto-lost-its-meaning

Doucet, Michael and John Weaver (1991). Housing the North American City. Montreal: McGill University Press.

Dreschel, Andrew (2015). "Should McMaster pay to police student parties?" Hamilton Spectator, October 2, 2015, pp. A15. 
Ennis, Debra (2006). “Letter - Missing the message," Hamilton Spectator, April 10, 2006, pp. A16.

Falkner, Rob (2006). "Big Mac attack; New, militant community group films drunken students and considers lawsuit against the university in effort to have campus pub closed," Hamilton Spectator, October 21, 2006, pp. A14.

Friedlander, Laura J., et. al. (2007). "Social Support, Self-Esteem, and Stress as Predictors of Adjustment to University Among First-Year Undergraduates," Journal of College Student Development vol. 48, no. 3, pp. $259-274$.

Fragomeni, Carmela (2015). "Folks oppose 15-room student home," Hamilton Spectator, April 3, 2015.

Fragomeni, Carmela and Dan Nolan (2015). "Brothers charged after four stabbed at house party; Witnesses describe chaotic scene at home in west-end neighbourhood," Hamilton Spectator, March 19, 2015, pp. A1.

Fragomeni, Carmela (2016). "Downtown tower for Mac students approved by planning committee," Hamilton Spectator, February 17, 2016.

Grant, Jill (2002). "Mixed Use in Theory and Practice: Canadian Experience with Implementing a Planning Principle," Journal of the American Planning Association vol. 68, no. 1, pp. 71 - 84.

Gumprecht, Blake (2006). "Fraternity Row, The Student Ghetto, and The Faculty Enclave: Characteristic Residential Districts in the American College Town," Journal of Urban History vol. 32, no. 2, pp. $231-273$.

Howard, Robert (2012). "McMaster 'bar fight' is ill-advised, uninformed," Hamilton Spectator, May 8, 2010, pp. A10.

Hubbard, Phil (2009). "Geographies of studentification and purpose-built student accommodation: leading separate lives?" Environment and Planning A vol. 41, pp. 1903 - 1923.

Hundscheid, John (2010). "Raising Cain: The University Student and the Politics of Protest," Academic Questions vol. 23, pp. 225 - 234.

Kenyon, Elizabeth L. (1997). "Seasonal Sub-Communities: The Impact of Student Households on Residential Communities," The British Journal of Sociology vol. 48, no. 2, pp. 286 - 301.

LaDousa, Chaise (2007), “'Witty House Name': Visual Expression, Interpretive Practice, and Uneven Agency in a Midwestern College Town," Journal of American Folklore vol. 120, pp. $445-481$.

Macintyre, Nicole (2006). "Westdale residents rally for city's help," Hamilton Spectator, October 23, 2006, pp. A08. 
Mckay, Barb (2005). “Neighbours protest student housing," Hamilton Spectator, December 5, 2005, pp. A03.

McMaster University (2015). “Welcome Week, 2015" Student Success Centre, URL retrieved from: http://studentsuccess.mcmaster.ca/students/orientation/welcome-week.html

McMaster University (2016). "McMaster Fast Facts," McMaster Office of Public Relations, URL retrieved from: http://www.mcmaster.ca/opr/html/opr/fast_facts/main/about.html

Mewdell, Melissa (2004). "Developers will transform CNIB into student housing; Eight buildings will house about 200 students, mostly from McMaster," Hamilton Spectator, October 4, 2004, pp. A04.

Municipal Property Assessment Corporation (2016). "Property Codes," URL retrieved from: https://www.mpac.ca/PropertyOwners/MPACsRole/PropertyCodesInventory

Munro, Moira, Ivan Turok, and Mark Livingston (2009). "Students in cities: a preliminary analysis of their patterns and effects," Environment and Planning $A$ vol. 41, pp. 1805 - 1825.

Northcott, Mary (2007). "Letter - Students and their cars in Ainslie Wood create a hazard," Hamilton Spectator, March 23, 2007, pp. A14.

Peters, Jeff (2003). "Knocking on a party house door; Students in the house went too far. They made his mom cry," Hamilton Spectator, May 1, 2003, pp. A15.

Peters, J.J. (2006). "Letter - Focus on student behaviour," Hamilton Spectator, April 6, 2006, pp. A19.

Robb, George (1970). McMaster University Student Housing and Related Needs Program: Final Report. Toronto, George Robb Architects.

Robinson, Judy (2007). "Letter - Mac should concentrate on controlling students," Hamilton Spectator, April 27, 2007, pp. A14.

Rugg, Julie, David Rhodes, and Anwen Jones (2002), "Studying a Niche Market: UK Students and the Private Rented Sector," Housing Studies vol. 17, no. 2, pp. 289 - 303.

Sage, Joanna, Darren Smith, and Phil Hubbard (2012). "The Rapidity of Studentification and Population Change: There Goes the (Student)hood," Population, Space and Place vol. 18, pp. $597-613$.

Sears, Henry (1969). Room To Learn, Ottawa: The Runge Press.

Selwyn, Neil (2008). “'High-jinks' and 'minor mischief': a study of undergraduate students as perpetrators of crime," Studies in Higher Education vol. 22, no. 1, pp. 1 - 16. 
Scapinello, Lori and John (1999). "Letter: Do something very soon - Student housing," Hamilton Spectator, May 31, 1999, pp. A10.

Sher, Jonathan (2009), "Council OKs licence for small landlords," London Free Press, September 22, 2009, retrieved from the London Free Press website:

http://www.lfpress.com/news/london/2009/09/22/11046991-sun.html

Simpson, Lesley (1997). "The ghettoization of Westdale: Neighbours fear 12 university-owned houses may fall into hands of absentee landlords," Hamilton Spectator, June 17, 1997, pp. A1.

Smith, Cameron J. and Todd A. Randall (2008), "Measuring Residential Lot and Neighbourhood Changes in Hamilton, Ontario," Canadian Journal of Urban Research vol. 17, no. 1, pp. 155 164.

Smith, Darren (2008). "The Politics of Studentification and '(Un)balances Urban Populations: Lessons for Gentrification and Sustainable Communities?" Urban Studies vol. 42, no. 12, pp. $2541-2564$.

Statistics Canada (2014). "Section W: Education”, Historical Statistics of Canada, July 2, 2014, URL Retrieved from: http://www.statcan.gc.ca/pub/11-516-x/pdf/5220023-eng.pdf

Statistics Canada (2015). "Postsecondary enrolments by institution type, registration status, province and sex," November 30, 2015, URL Retrieved from: http://www.statcan.gc.ca/tablestableaux/sum-som/101/cst01/educ71a-eng.htm

Thomsen, Judith (2007). "Home Experiences in Student Housing: About Institutional Character and Temporary Homes," Journal of Youth Studies vol. 10, no. 5, pp. 577 - 596.

Thomsen, Judith and Terje Andreas Eikemo (2010). "Aspects of student housing satisfaction: a quantitative study," Journal of Housing and the Built Environment vol. 25, pp. 273 - 293.

Thompsen, Nicole. "McMaster announced new multi-purpose building," Hamilton Spectator, June 15, 2015.

University of Ottawa (2016). "Housing services - Houses," University of Ottawa Off-Campus Housing, URL retrieved from: https://www.uottawa.ca/housing/compare-residences/houses

Wilson, Paul (2005). 'It's the latest -- live in a strip mall; The developer's getting cold feet, but what's wrong with calling a plaza home? Plus, fine dining comes to the place where La Costa died," Hamilton Spectator, February 3, 2005, pp. G02. 